支部・集談会記事

\section{日本臨床外科学会北海道支部抄録 (第113回北海道支部総会)}

\author{
日 時：平成30年 7 月28日（土） $8 ： 25$ \\ 会 場：星野リゾート OMO7旭川 \\ 第 1 会場 2 階 北斗の間 \\ 第 2 会場 2 階 北辰の間 \\ 支部長：竹政 伊知朗 \\ 会 長：矢吹 英彦
}

\section{学会賞選考発表会}

I 日本人乳癌患者の肥満と予後に関する検討

札幌医科大学 消化器 - 総合、乳腺・内分泌外科

○和田朝香、九冨五郎、島 宏彰、里見蕗乃、中津川智子、竹政 伊知朗

【背景】肥満が乳癌の発症リスクであることは確実となっており、 予後への影響も欧米諸家により報告されている。しかし、アジア 人での肥満と予後の関連は十分に検討されておらず、比較的瘦せ 形であるアジア人を欧米人と一様に考えることはできない。

【目的】日本人乳癌女性の肥満と予後の関連を検討し、最も予後 に影響する肥満度を見出すこと。

【対象と方法】2011年 1 月から2016年12月に当科で手術を施行し た原発性乳癌患者479例を対象とした。両側、男性、外国人、初 診時 stage IV 乳癌の 8 例を除外した。肥満度はBMIで評価し、 DFSに対する比例ハザード分析にてBMIの至適カットオフを求 めた。予後はDFS (disease-free survival)、BCSS (breast cancer specific survival）で評価した。年齢、生活歴（飲酒歷、喫煙 歴、糖尿病の有無)、病理所見 (病理学的浸潤径・核グレード . $\mathrm{ER} \cdot \mathrm{PgR} \cdot \mathrm{HER} 2$ ・リンパ節転移の有無・脈管侵襲の有無）に ついて肥満群と非肥満群の 2 群間で比較した。

【結果】解析対象は 471 例であり、年齢中央值は59歳 $(28-89$ 歳)、 観察期間中央值は38か月（1-86か月）であった。BMIの至適力 ットオフ值はDFS、BCSS共にBMI27であった（DFS: HR 4.62, $\mathrm{p}<0.001$; BCSS: HR 4.58, p=0.003)。BMI $\geqq 27$ の肥満群は88例 $(18.7 \%) 、<27$ の非肥満群は383例 $(81.3 \%)$ であり、肥満群では 年齢50歳以上、糖尿病、腫瘍径高值、リンパ節転移陽性が有意に 多い結果であった。局所再発・転移は41例［肥満群19例（22\%）、 非肥満群 22 例 $(6 \%)$ ]、死亡は15例 [肥満群 7 例 $(8 \%)$ 、非肥 満群 8 例 $(2 \%)$ ] に認めた。DFSに対する多変量解析の結果、 予後不良因子は肥満、腫瘍径高值、リンパ節転移陽性であった。 Propensity matchingにより背景因子調整したDFSは有意に BMI27以上の症例で不良であった $(\mathrm{p}=0.007)$ が、BCSSは有意 差が見られなかった $(\mathrm{p}=0.127)$ 。背景因子調整前は、DFS、 BCSS共に有意差が見られた結果であった（DFS: $p<0.001$; BCSS: $\mathrm{p}=0.006$ )。

【結語】肥満は乳癌の予後不良因子であることが日本人患者にお いても既報同様に示唆され、BMI 27 が至適カットオフとなる結果 が得られた。交絡因子を調整しても肥満は乳癌の独立した予後不 良因子となり得る結果であり、肥満を予防する取り組みは今後の 診療に拈いて考慮すべき課題となると考えられた。

\section{II 深達度診断からみた噴門側胃切除の手術適応について の検討}

旭川医科大学 外科学講座消化器病態外科学分野

○庄中達也、長谷川公治、大谷将秀、合地美香子、谷 誓良、宮 本正之、古川博之

【緒言】2018年 1 月に改定された胃癌治療ガイドライン第 5 版で は、U 領域の cT $1 \mathrm{~N} 0$ 胃癌への噴門側胃切除が弱く推奨されてい る。また、同ガイドラインには胃癌の術前での深達度診断には限 界がある、とも記載されている。つまり噴門側胃切除の手術適応 とした症例の一部は進行癌であり、縮小手術による腫瘍学的な問 題が生じる可能性がある。【目的】噴門側胃切除の適応となりう る U 領域 $\mathrm{CT} 1$ 胃癌の術前正診率とその病理学的評価を評価する。 【対象】当院で2002年 1 月から2010年12月末までに当科で胃癌手 術を行った471例中占拠部位がU 領域の胃癌で根治手術を施行し たのは92例であった。うち $\mathrm{cT} 1 ： 37$ 例を $\mathrm{pT} 1$ と $\mathrm{pT} 2$ 以深に分 け比較検討した。pT $1: 28$ 例、pT 2 以深： 9 例 (24.3\%) であった。 カルテを用い後方視的に検討した。術前深達度診断は内視鏡およ びバリウム・CTでの総合診断とした。記載は胃癌取扱い規約第 15版、胃癌治療ガイドライン第 5 版に基づき再評価した。【結果】 年齢は72（35-86）歳、性別は男性：女性＝31:6であった。術式 は胃全摘34例、幽門側胃切除 2 例、噴門側胃切除 1 例であった。 リンパ節郭清はD $1 ： 20$ 例、D 1 + : 15例であった。占拠断面で はpT 2 以深は小彎（ 6 例 $)$ 後壁（3 例）側のみであった。腫瘍 径も pT $1: \mathrm{pT} 2$ 以深 $=23.1 \pm 11.9 \mathrm{~mm}: 39.4 \pm 26.2 \mathrm{~mm}$ と $\mathrm{pT} 2$ 以深 で有意に腫瘍径が大きかった $(\mathrm{P}=0.01)$ 。「占拠断面が小彎ないし 後壁である腫瘍径 $25 \mathrm{~mm}$ 以上」の病変は有意に $\mathrm{pT} 2$ 以樑であっ た $(\mathrm{P}=0.04)$ 。 $\mathrm{cT} 1$ 症例の $\mathrm{pN}(+)$ は 5 例 $(14.2 \%)$ で転移リン パ節転移は\#1,3,7,11pであった。 5 年生存率はpT $1: 96.3 \%$ に対し pT 2 以深は $55.6 \%$ でったが、再発は pT 4 a 症例の腹膜再発の 1 例のみであった。【結語】U領域にある $\mathrm{cT} 1$ 胃癌で $\mathrm{pT} 2$ 以深

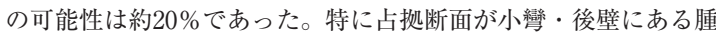
瘍径 $25 \mathrm{~mm}$ 以上のものは $\mathrm{pT} 2$ 以深の可能性がある。しかし、cT 1 症例に噴門側胃切除を施行しても腫瘍学的な問題は生じないと 思われる。

\section{III高齢者胃癌（80歳以上）に対する腹腔鏡下胃全摘術の 治療成績（多施設共同後乃向き研究）}

北海道大学大学院医学院 ·医学研究院 消化器外科学教室 II ${ }^{1}$ 、 手稲溪仁会病院 外科 2 、带広厚生病院 外科 3 、北海道消化器科 病院 外科 4 、斗南病院 外科 $^{5}$

○城崎友秀1、海老原裕磨1、中西喜嗣1、浅野賢道1、野路武寛1、 倉島 庸 ${ }^{1}$ 村上壮一1、中村 透1 、土川貴裕 ${ }^{1}$ 、七戸俊明 1 、平野 聡1、 中村文隆 2 、村川力彦 3 、森田高行 4 、奥芝俊一 5

【背景と目的】

昨今、胃癌の罹患数は減少傾向にあるものの、社会人口の急速な 高齢化社会を迎える我が国では、今後、除菌未施行例や除菌後発 症の高齢者胃癌の割合が増加するものと考えられる。一方、高齢 者に対する癌治療では、フレイルやサルコペニアといった特有の 身体状況や併存疾患を考慮し、低侵襲手術や臟器温存手術をいか に適切に適応するかが重要課題と考えられる。そこで今回、教室 関連施設における高齢者（80歳以上）に対し腹胫鏡下胃全摘術 (LTG: Laparoscopic Total Gastrectomy) を行った症例を集積し、 その治療成績につき検討を行った。

【対象・方法】

2004 年 3 月より 2016 年 12 月までの間に当科および関連 5 施設にお いてLTGを施行した398例を対象とした。その中から、年齢80歳 
以上の37例 (高齢者群) と65歳未満の152例(若年者群) を抽出し、 両群における手術関連因子や長期成績について後方視的に比較検 討を行った。

【結果】

両群間の比較で術前 ASA 分類 class 3 以上は高齢者群で 6 例 $(16.2$ $\%) 、$ 若年者群で 3 例 $(1.9 \%)$ であり、有意な差を認めた（P $<$ 0.001）が、術前Stageに差は認めなかった。手術は高齢者群にお いてガイドラインの推奨郭清度未満の手術が多く施行されており $(\mathrm{P}<0.001)$ いた。手術時間の中央值（範囲）は、高齢者群で263 分（117-525）に対し、若年者群で338分（193-762）で、高齢者 群において有意に手術時間が短いが $(\mathrm{P}<0.001)$ 、術中出血量に 差は認められず、術後合併症（Clavien-Dindo分類 II 以上）にも 差を認めなかった。pStageおよび術後再発率に両群間に差は認 められなかった。ガイドラインが推奨する術後補助化学療法施行 例は高齢者群で有意に少なかった $(\mathrm{P}<0.001)$ 。 5 年 Overall SurvivalならびにDisease Specific Surviva（1 DSS）はいずれも高齢 者群で有意に不良であった $(\mathrm{P}=0.006, \mathrm{P}=0.024)$ 。

\section{【まとめ】}

高齢者胃癌患者に対するLTGは安全に施行されていたが、高齢 者群において術前状態不良により郭清を手控えた手術、あるいは 術後化学療法を控えた症例が多く、DSS減少の一因の可能性があ る。今後、高齢胃癌者に対する至適郭清範囲ならびに術後化学療 法施行の適応につき、さらなる検討が必要である。

$\mathrm{N}$ 腹脘鏡下大腸切除に抢ける技術認定の位置付け

北海道大学 消化器外科 I

○市川伸樹、本間重紀、吉田 雅、川俣 太、柴崎 晋、川村秀 樹、武冨紹信

背景：腹腔鏡下大腸切除において, 技術認定は技術の伝承および 質の担保に貢献していると考えられるが, その文献的根拠は乏し い。

目的：1）技術伝承への寄与を検討する為, 後進の技術認定取得 における技術認定医介入の有用性を評価する。2）質が担保を検 討する為, 新規技術認定医による腹腔鏡下低位前方切除の手術成 績を評価する。

方法：1）技術認定取得可能年次の 2 術者において, 技術認定医 介入と非介入による腹腔鏡下高位前方切除の手術成績を比較し, cumulative sum (CUSUM) 解析と連続 5 症例ずつの移動平均法 を用い, 手術時間の短縮効果を比較検討する。2）3人の技術認 定医における, 技術認定取得直後からの腹䏶鏡下低位前方切除の 成績を示す。また， 3 術者の手術時間平均に関する移動平均と CUSUM 表を描出し, 技術認定取得時の目標達成度を評価する。 結果：1）技術認定介入では63.5歳, BMI22.0, 腫瘍最大径 $33.3 \mathrm{~mm}$ の男性14女性 6 名, 非介入では65.5歳, BMI23.50, 腫瘍 径33.9mm の男性15女性 4 名の大腸癌に対し高位前方切除が施行 された。手術時間は介入 194 分に対し, 非介入は 250 分と有意に長 かった。出血量はそれぞれ14.1対 $34.0 \mathrm{ml}$, Clavien-Dindo 3 以上の 合併症は 2 対 1 例（縫合不全無し）で差を認めなかった。移動平 均による手術時間の評価では，介入では227から170分へ持続的に 短縮傾向を示したが, 非介入で短縮傾向を示さず, 介入で 7 平均 以降に有意な手術時間短縮を認めた。技術認定取得条件の目安と される180分を目標值としたCUSUMでは, 介入で 7 症例目より 目標値との時間差がプラトーに達したが非介入では持続的な増加 を認めた。以上より後進の技術認定取得における技術認定医介入 の有用性の可能性が示された。2）3人の新規技術認定医により， それぞれ7,19,19例ずつの低位前方切除（TMSE，DST）が行われ
た。対象患者全体では平均63.1歳, 男性17名女性28名, BMI23.6, 腫瘍最大径41.1mm でD 3 郭清は39例 (84\%) に, 回腸瘦併設は 8 例 (17\%) に行われた。平均手術時間202分, 出血量 $13.2 \mathrm{ml}$ で, 開腹移行は認めず, 合併症は 4 例 $(8.6 \%)$ （縫合不全 2 例 $(4.3 \%))$ に認めた。患者背景, 周術期成績に術者間の差異を認めなかった。 3 術者の平均手術時間を移動平均法で評価すると, 症例を重ねる ことで 233 から 174 分へ軽快し, エキスパートの手術時間を参考に 設定した目標値180分に対するCUSUMで評価すると, 12例目を ピークに目標値との時間差が正から負へと移行した。技術認定取 得時においても短期成績は良好で, 質の担保は得られるが、エキ スパートと同等の手術パフォーマンスを得るためには, 更なる $(12$ 例の）修練期間を要した。

結語：腹腔鏡下大腸切除において, 技術認定は技術の伝承および 質の担保に寄与している可能性がある。しかし, 認定取得後にも 学習効果は存在し, 修練を重ねる必要がある。

\section{一般演題}

1 Micronodular thymoma with lymphoid stromaの 切除例

NTT 東日本札幌病院 外科 1 、北海道大学 循環器 - 呼吸器外科 ${ }^{2}$ 青木佑磨1 、道免寛充 ${ }^{1} 、$ 樋田泰浩 2 、猪子和穂 1 、古川聖太郎 1 、市 之川一臣、山田秀久 ${ }^{1}$

Micronodular thymoma with lymphoid stroma（以下 MNT）は 胸腺腫の中でも $1 \%$ と稀な組織亜型である。今回我々はMNTの 一切除例を経験したので報告する。症例は67歳、女性。高血圧と 糖尿病で前医通院中にスクリーニング目的で行った胸部単純 CT で前縦隔に占拠性病変を指摘され当科紹介となった。胸部造影 CT で前縦隔に $80 \times 60 \mathrm{~mm}$ 大の比較的境界明瞭で多結節状の軟部 濃度腫瘤を認めた。胸部単純 MRIでは T 1 強調、T 2 強調のいず れも低信号を示した。FDG-PETではSUVmax4.6の集積立進を 認めた。腫瘍性病変を疑い胸腔鏡下胸腺全摘術を施行した。経過 良好で術後 7 日目に退院した。病理学的には比較的異型の乏しい 上皮系腫瘍細胞が胞巣を形成し、散在するリンパ滤胞の主成分で ある B cellを含む豊富なリンパ性間質を有する腫瘍で、MNTと 診断された。

\section{2 経鼻胃管による気管支損傷に対して保存的療法で改善 した 1 例} 市立釧路総合病院 外科

井上 玲、大塚慎也、廣瀬和幸、宮崎 大、齋藤博紀、福田直也、 佐藤暢人、飯村泰昭、長谷川直人

経鼻胃管によって気管支穿孔を来たし, 保存的療法で軽快した 1 例を経験したので報告する。症例は70代女性、施設入所中に栄養 目的の経鼻胃管を挿入された。翌日レントゲン検查にて胃管の右 気管支への誤挿入と気管支穿孔を疑う所見があり当科紹介となっ た。気管支鏡検查にて中間気管支幹の膜様部と軟骨部の境界部に スリット状の穿孔部位を認めた。胸腔ドレーンを挿入し、リーク は認めなかった。呼吸状態は安定していたため、保存的治療の方 針とした。肺炎に対して抗生剂治療を開始した。感染の悪化なく 経過し、2 週間後に施行した気管支鏡検査では損傷部の閉鎖をみ とめた。その後、損傷部周囲の気管支の狭窄の所見は認めていな い。気管支損傷の治療の原則は早期の外科治療とされるが小裂傷 の場合には保存的治療で改善をすることもある。また遅発性の狭 窄などの可能性もあり、症例に応じて治療法を考慮する必要があ ると考えられた。 
3 高度癒着を伴う気胸に対して胸膜外剥離、瘦孔内生体 糊・PGA シート注扦入が有効であった 1 例

札幌医科大学 呼吸器外科

大川美穂、三品泰二郎、槙龍之輔、高橋有毅、多田 周、新井 航、 宮島正博、渡辺 敦

【背景】気胸の手術は、低呼吸機能や病変部位、癒着の程度によ って肺部分切除や縫合・縫縮が困難である。今回我々は高度癒着 を伴う気胸に対し胸膜外剥離、瘦孔内生体糊・PGA シートを注 挿入した症例を経験した。【症例】70歳男性。数か月前からの呼 吸困難感で前医を受診し左気胸の診断となった。胸䏶ドレーン挿 入14日目に転院となり、全身麻酔で胸腔鏡手術を実施。肺尖部及 び舌区は広範囲に癒着し胸膜は白色肥厚していた。肺尖部の孔か らリークを確認したが、肺実質の瘦孔はさらに深部に存在すると 考えた。剥離はリスクが高いと判断し、孔から腹側の壁側胸膜を テント状に剥離しポケット作成、生体糊と PGA シートを瘦孔内 に注挿入、さらにポケットの入り口をフェルト付き $3-0$ prolene 3 針で縫合閉鎖した。術後 1 日目にドレーン抜去。術後 8 日目に 退院した。【結語】胸膜外剥離、生体糊・PGA シート注挿入法は、 肺剥離が困難な高度癒着を伴う気胸症例に対し有用な方法と考え る。

\section{4}

非侵襲的陽圧換気長期装着 CMT 症例に繰り返す続発

性気胸

札幌医科大学 呼吸器外科

三品泰二郎、渡辺 敦、宮島正博

人工呼吸器を装着した患者が気胸を発症した場合、陽圧換気であ るため難治性気胸となる。症例は38歳男性。Charcot-MarieTooth病 (CMT) の診断で夜間に非侵襲的陽圧換気（NPPV）を 装着している。経過）36歳時に初回左気胸に対して胸腔ドレナー ジ施行。NPPV休止により 5 日目にドレーン抜去し退院となった。 2 年後に 2 回目左気胸発症。胸腔ドレナージ施行・NPPV 休止も リーク持続するため自己血注入療法を 2 回施行。リーク消失を確 認し12日目にドレーン抜去し退院。考察) CMTは筋力低下と感 覚障害を示す疾患である。重症例では、呼吸不全を来たし人工呼 吸器を必要とする場合もある。難病に伴うNPPV 続発性気胸症例 ではリスクが高く、手術困難と判断される場合がある。保存的治 療で改善する場合もあり、個々の症例に応じて判断し、適切に治 療方針を決定する必要がある。

\section{5 右肺上葉切除後に中葉軸捻転をきたした 1 例}

\section{勤医協中央病院 外科}

諸星直輝、川原洋一郎、松毛真一、松田隆志、石井健一、奈良智 志、中村祥子、阿部慎司、大黒聖二、田尾嘉浩、林 浩三、吉田 信、後藤 剛、山川智士、鎌田英紀、高梨節二、樫山基矢、石後 岡正弘、河島秀昭

肺切除後のまれな合併症として肺軸捻転があるが, 対処が遅れる と致命的となりうる. 今回, 右上葉切除後に中葉軸捻転をきたし た 1 例を経験したので報告する。症例は71歳女性. 4 年前に乳腺 葉状腫瘍に対して乳房切除術を施行した。 1 年 6 ケ月前の胸部 CTで右 S 2 に $10 \mathrm{~mm}$ のすりガラス影が出現した。徐々に増大し, 1 ケ月前の胸部 CTで $2 \mathrm{~mm}$ の充実性成分を伴った $21 \mathrm{~mm}$ のすり ガラス影となった. 右上葉肺癌の疑いで, 胸臆鏡下右上葉切除 ND 1 b 郭清を施行した。 上下葉間は完全分葉であった。術翌日 の胸部レントゲンで中葉の含気不良を認め, 胸部 CTで中葉の完 全無気肺を認め, 中葉軸捻転疑いで再手術とした。 中葉は反時計
周りに180度捻転していたが，色調は良好であったため捻転を整 復した．捻転防止のため中葉と下葉を 2 箇所結紫し固定した．初 回手術後10日目に退院となった。

\section{6}

例

函館市医師会病院

桐山琴衣、黒川貴則、金子行宏、和田雅孝、本原敏司 症例：70歳代、女性。既往歴として、甲状腺乳頭癌に対し右葉切 除術 $+\mathrm{D} 2 \mathrm{a}$ リンパ節郭清を施行し、病理組織学的にPapillary carcinoma, pT 1 b, Ex 0, N1b（\#2 2/7, \#7 1/11） と 診断されていた。外来にて経過観察中、術後13年目のCTで左肺 舌区に辺縁整・境界明暸な円形の $9 \mathrm{~mm}$ の結節を認めた。その後 緩徐な増大傾向を示し、 3 年後には $13 \mathrm{~mm}$ となり、甲状腺乳頭癌 の肺転移を疑い、胸胫鏡下左肺舌区切除を施行した。病理組織学 的に、Papillary carcinomaで、甲状腺乳頭癌の肺転移と診断さ れた。術後経過は良好で、術後 8 病日目に軽快退院となり、現在 無治療経過観察中であるが、無再発生存中である。

甲状腺乳頭癌は緩徐な経過をたどることが多く、術後長期間のフ オローアップが必要である。今回我々は、術後13年目に孤立性肺 転移を来した甲状腺乳頭癌の 1 例を経験したので、若干の文献的 考察を加え報告する。

7 肺原発Lymphoepithelioma- like carcinomaの 1 例 札幌南三条病院 呼吸器外科 佐々木明洋、加地苗人、長靖、野村俊介 肺原発 Lymphoepithelioma-like carcinoma (LELC) はEB virus (EBV) との関連が前提となる稀な疾患である。今回、肺原発 LELCの 1 例を経験したので、文献的考察を加え報告する。症例 は60歳女性。健診で胸部異常陰影を指摘され、当院呼吸器内科を 受診した。CTで分葉不全部の左 S $5 / \mathrm{S} 8$ に27 mm大の結節を認 めた。採血で EA-IgGが高值であり EBV との関与が示唆された。 経気管支肺生検を施行しLELCの診断となった。手術目的に当科 紹介受診となり、左舌区・底区域切除＋ND $2 a-2$ を施行した。 病理組織所見ではリンパ球、形質細胞の浸潤とリンパ濾胞形成が 著明で、EBV-encoded small RNAのin situ hybridizationが陽 性であり LELC、pT 2 aN 0 M 0 、pStageIB と診断した。

8 直腸癌術後に孤発性縦隔転移をきたした 1 例 札幌医科大学 消化器 · 総合、乳腺 ·内分泌外科 小助川紗弥、沖田憲司、西涻敏彦、奥谷浩一、碓井彰大、秋月恵 美、石井雅之、里吉哲太、待木隆志、竹政伊知朗

【はじめに】直腸癌の孤発性縦隔リンパ節転移は非常に稀である。 今回、我々は直腸癌術後に弧発性縦隔リンパ節転移を来たした症 例を経験したため報告する。【症例】55歳、男性。肛門痛と下血 を主訴に前医を受診し、直腸癌の診断で当科紹介となった。術前 化学療法 XELOX 4 コース施行後にロボット支援腹腔鏡下超低 位前方切除術を施行した。ypT 3 N 2 M 0 ypStage III b 病理組織 学的効果判定Grade 2 の診断で術後補助化学療法XELOXを 4 コ 一ス施行した。術後約 9 か月に孤発性縦隔リンパ節転移の診断と なり、RAS wildであったためFOLFIRI+Pmabを 8 コース施行 後に胸腔鏡下縦隔リンパ節郭清術を施行した。S- 1 内服を 5 コ 一ス施行し、現在術後 7 か月経過するが無再発生存中である。【結 語】直腸癌術後の孤発性䋛隔リンパ節転移をきたした症例に対し て集学的治療により R 0 を得られた症例を経験した。 
9 肺原発の炎症性筋線維芽細胞腫瘍の一例 旭川医科大学 呼吸器センター1、旭川医科大学病院 手術部 2 石橋 佳 ${ }^{1}$ 安田俊輔 1 、高橋奈七 ${ }^{1}$ 、岡崎 智 1 、北田正博1、平田 智2

【症例】19歳男性. 健診で左肺異常影を指摘され, 精查目的に呼 吸器内科を受診した. CT 上左肺下葉に $2.4 \times 2.1 \mathrm{~cm}$ の境界明瞭平滑 な淡い造影効果を示す腫瘤を認め, FDG-PETでは同部位に集積 が認められ, 画像上はカルチノイドが疑われたため, 手術目的に 当科へ紹介となり, 胸腔鏡下左肺下葉部分切除術を施行した. 病 理所見では, 腫瘤は正常組織と境界明瞭な結節性腫瘤であり, 紡 錘形細胞が束状に増殖する像が認められた。免疫染色では, S-100 - chromogranin · CK $7 \cdot \mathrm{CK} 20 \cdot \mathrm{TTF} 1$ などは陰性で, 形 態・免疫特性からカルチノイドや原発性肺癌は否定的であった. また, vimentin・bcl-2が陽性であり, solitary fibrous tumor と の鑑別が問題となったが, ALKが陽性, CD34・STAT 6 などが 陰性であったため, inflammatory myofibroblastic tumorの診断 となった. 切除断端は陰性で, 術後半年現在再発を認めず良好に 経過している.【考察】炎症性筋線維芽細胞腫瘍 (IMT ; inflammatory myofibroblastic tumor) は肺切除例の0.04-1\%と比較的 稀な疾患であり, 多くは40歳以下の若年に発症することが知られ ている。 今回我々は19歳男性に生じ, 画像上カルチノイドが疑わ れたが, 病理学的に確定診断に至った肺原発のIMTの一例を経 験した。症例について文献的考察を加え報告する。

10 肺腺癌と混合型大細胞神経内分泌癌の異時性多発肺癌 に対する 1 手術例

札幌医科大学 呼吸器外科

槙龍之輔、宮島正博、高橋有毅、多田 周、新井 航、大川美穂、 三品泰二郎、渡辺 敦

混合型大細胞神経内分泌癌 (combined LCNEC) はLCNECに他 の組織型を混在した組織型であり、LCNECの約 $10 \%$ と稀な組織 型である。今回、右上葉と右中葉に発生した肺腺癌と混合型大細 胞神経内分泌癌の異時性多発肺癌に対して手術を施行した症例を 経験したので報告する。症例は、76歳男性。重喫煙者であり、慢 性腎不全にて血液浄化療法を受けている。 5 年前に右中葉原発の 肺腺癌と診断され、ゲフィチニブによる分子標的療法を受けてい た。その後、腫瘍の増大を認めたため再生検を施行したところ EGFR T790M 陽性を認め、オシメルチニブによる加療に変更さ れた。同時期に右上葉に結節影を認めたため生検をしたところ、 扁平上皮癌の診断となった。扁平上皮癌に対して cT $2 \mathrm{bN} 0 \mathrm{M} 0$ 、 肺腺癌に対してycT $2 \mathrm{aN} 0 \mathrm{M} 0$ の診断となり、外科療法の方針 となった。肺腺癌と扁平上皮癌の異時性多発肺癌に対して胸䏶鏡 下右上中葉切除+ND 2 a- 2 を施行した。術後経過は良好で、最 終病理診断は右上葉混合型大細胞神経内分泌癌 ( $\mathrm{pT} 2 \mathrm{bN} 0 \mathrm{M}$ 0 )、右中葉肺腺癌（治療効果判定 Ef. 1 b、ypT 1 bN $0 \mathrm{M} 0$ ）と なり、リンパ節転移を認めなかった。

11 巨大肝 multicystic biliary hamartomaの 1 例 $\mathrm{JA}$ 北海道厚生連 旭川厚生病院 外科 ${ }^{1} 、 \mathrm{JA}$ 北海道厚生連 JA 北海 道厚生連 旭川厚生病院 消化器科 2 、旭川厚生病院 病理診断科 ${ }^{3}$ 西越崇博 1 、稲垣光裕 ${ }^{1} 、$ 佐野修平1、志智俊介 ${ }^{1}$ 、山田健司 1 、腰塚 靖之 ${ }^{1}$ 、芝木泰一郎 1 、柳田尚之 ${ }^{1}$ 、池上 淳 ${ }^{1}$ 赤羽弘充 ${ }^{1}$ 柳川伸幸 2 、 藤永明裕 ${ }^{2}$ 、佐藤啓介 ${ }^{3}$

はじめに：肝内の小さな multicystic biliary hamartoma (MBH) は散見されるが、肝外に大きく発育した MBHは稀である。今回
我々はCTにて指摘された肝外発育腫瘍を切除し、 $\mathrm{MBH}$ と診断 された 1 例を経験したので報告する。症例：46歳男性。声帯腫瘍 の術前精查で糖尿病を指摘され、血糖コントロール目的に代謝内 科に入院した。スクリーニング CTで肝囊胞性腫瘍を指摘され当 科紹介された。腹部CTで肝 S 5 から突出する $15 \times 15 \mathrm{~cm}$ 大の隔壁 が一部肥厚した多房性囊胞性腫瘤を認め、IVCを圧迫していた。 FDGPET/CTでは囊胞隔壁の一部にSUV max 1.9の軽度集積を 認めたが肝外病変は認めなかった。GSA肝シンチグラフィーで はHH15=0.56、LHL15=0.95 と肝予備能は良好であった。粘液産 生胆管腫瘍を否定できないため、手術切除の方針とし腫瘍切除+ 肝S 5 部分切除術を施行した。術後、病理組織学的検査では $\mathrm{MBH}$ と報告された。文献的考察を含め報告する。

12 ICG 蛍光観察下に施行した肝細胞癌に対する腹㛬鏡下 マイクロ波凝固療法 (MCT) の経験

札幌医科大学 消化器 - 総合、乳腺 - 内分泌外科

吉田瑛司、永山 稔、今村将史、山口洋志、藤野紘貴、木村康利、 水口 徹、竹政伊知朗

【はじめに】近年、インドシアニングリーン（ICG）を用いた術 中ナビゲーションが肝切除に用いられている。今回我々は、肝細 胞癌の腹腔鏡下 MCTにおける ICG 蛍光法併用の有用性を報告す る。【症例】57歳女性。B型慢性肝炎のフォロー中、CTで肝腫瘤 を指摘され当院紹介となった。肝 S 6 と S 2 にそれぞれ $4.0 \mathrm{~cm}$ 、 $0.8 \mathrm{~cm}$ の早期濃染、wash outを呈する腫瘍を認め、肝細胞癌と診 断した。手術 4 日前にICG を $20 \mathrm{mg} /$ body 投与し、腹腔鏡下肝 S 6 部分切除術、S 2 腫瘍に対しMCTを計画した。【手術所見】 S2 腫瘍は肝表に存在するが、肉眼で腫瘍は視認できなかった。ICG 蛍光法を用いると、標的は明瞭な蛍光像を呈し、IOUSに扔ける 同部位の hypoechoicな腫瘤と一致した。ICG蛍光法観察下に MCTを施行した。【術後経過】術後 7 日目のCTで腫瘍は十分に 焼灼されていた（TE 4 a)。【まとめ】ICG 蛍光法は、腹腔鏡下 MCTにおいてリアルタイムに腫瘍の局在を可視化でき、術中ナ ビゲーション法として有用であると考えられた。

13 術後長期無再発生存中の肝原発腺扁平上皮癌の 1 例 北海道大学病院 消化器外科 I

市村健太郎、神山俊哉、長津明久、大畑多嘉宣、島田慎吾、折茂 達也、横尾英樹、蒲池浩文、武冨紹信

肝原発腺扁平上皮癌は肝内胆管癌の特殊型であり，稀である。ま た活動性が高く，予後は極めて不良である．77歳女性．心窩部痛 を主訴に前医を受診. 肝内胆管癌の診断となり手術目的に当科を 受診した. CA19-9の上昇を認め, CT検查にて腫瘍は内側区, 外側区に位置し $51 \times 35 \mathrm{~mm}$ 大, 増強効果は弱く周囲との境界は不 明瞭であった，MRI検査では左肝管は腫瘍部位で途絶, 肝左葉 の肝内胆管の拡張を認め同部で腫瘍による浸潤が疑われた，腫瘤 形成型肝内胆管癌として, 肝左葉尾状葉切除 + 胆囊摘出 +リンパ 節郭清術を施行した. 術後経過は概ね良好で, 術後 24 日目に退院 した. 病理組織診にて腫瘍胞巣は明瞭な角化を示し中心壞死を呈 する部分と, 腺房状腺管状を呈し粘液産生がみられる部分とが混 在した所見を認め, 腺扁平上皮癌の診断に至った. 術後 5 年 2 力 月現在, 無再発生存中である. 肝原発腺扁平上皮癌は予後不良と されるが積極的に手術を行うことにより長期無再発生存を得た 1 例を経験した。 
14

門脈ガス血症の 1 例

小林病院

森山寬也、鈴木達也、重原健吾、山本康弘

門脈ガス血症は、多くの場合は腸管壊死などの重篤な腹垫内疾患 に伴って出現する予後不良の病態徴候とされる。今回我々は初診 時症状、所見にそしく、保存的加療を考えたが、急激な症状進行 を認め緊急手術に至った症例を経験した。症例は85歳男性。糖尿 病患者でボグリボース服用中。急激な腹痛があり救急要請したが、 症状消失。その後 3 時間程して症状再燃・增悪し救急搬送され当 院受診。初診時腹部平坦・軟で圧痛は認めるが腹膜刺激症状を認 めず、単純 CT で門脈ガス像認めたが腸管の明らかな搪張やイレ ウス像も認めなかったため保存的加療を考慮し入院。その後 30 分 程で腹痛增覀、腹部膨満出現し緊急手術となった。術中所見は混 濁した腹水、小腸の壊死を認め $270 \mathrm{~cm}$ 切除。術後は経過良好で退 院となった。門脈ガス血症は近年保存的加療での改善例も報告さ れているが、急激な症状の進行を認めた場合は審查腹腔鏡を含む 緊急手術が重要である。

験

旭川医科大学 外科学講座 消化器病態外科学分野

萩原正弘、川原敏靖、水上奨一朗、高橋裕之、金澤宽之、今井浩 二、松野直徒、古川博之

【はじめに】当科では当院の倫理委員会の承認を得て、臨床研究 としてロボット支援下肝切除術を施行している。現在までは 2 例 経験をして、いずれも肝切離はロボットアームを用いた clamp crashing methodで行った。今回は通常当科で肝切除時に使用し ているCUSAを用いたロボット支援肝S 3 亜区域切除術を経験し たので報告する。

【症例】70歳代、男性。近医に脂肪肝で通院中、肝腫瘤性病変を 指摘され前医に紹介。精查にて肝細胞癌の診断で手術目的に当科 入院。ICG R15 17.9\%、Child Pugh Score A (5 点)、肝S 3 に $2.9 \mathrm{~cm}$ の単発腫韵を認めロボット支援肝 S 3 亜区域切除予定とし た。臍部よりカメラポート $(12 \mathrm{~mm})$ を挿入、ロボット支援専用 ポートを右季肋下に 1 本、左季肋下に 2 本㨂入した。さらに CUSA 用 $(12 \mathrm{~mm}) 、$ Pringle 用 $(12 \mathrm{~mm}) 、$ 吸引用ポート $(5 \mathrm{~mm})$ を扱入した。ロボットを用いて肝 S 3 門脈を同定、処理。demarcation lineを確認後にマーキングしてPringleを併用下にCUSA を用いて肝切離施行。ロボットアームは術野展開やクリッピング、 結炛に使用。手術時間 7 時間 28 分、出血量 $20 \mathrm{ml}$ 。術後経過は良 好で合併症なく術後 7 日目に独歩退院。

【結語】今回CUSA を用いたロボット支援肝 S 3 带区域切除術を 経験した。ロボット支援下肝切除における肝切離は clamp crashing method、CUSAいずれの方法でも安全に施行できると考え られた。

16

南回り B $2 / 3$ 胆管を伴う肝左葉グラフトを用いた生 体肝移植の一例

北海道大学 消化器外科 I 1 、北海道大学 臟器移植医療部 ${ }^{2}$

高橋直規、後藤了一1、渡辺正明2、川村典生 2 、財津雅昭1、神山 俊哉1、鴆村 剛、武富紹信 ${ }^{1}$

【背景】各種脈管の解剖の理解は肝移植の術式決定に不可欠であ る。今回、稀な南回り B $2 / 3$ 胆管を伴う肝左葉グラフトを用い た生体肝移植を経験した。

【生体肝移植ドナー】20代女性。父が成因不明の肝硬変（CTP 13
点C、MELD 27点) であり生体ドナー評価。腹部CTで脂肪肝無 く、肝左葉のグラフト容積 $(\mathrm{Gv}) 378 \mathrm{~g}, \mathrm{Gv} /$ 標準肝容量 $(\mathrm{Sv})$ 比 $32.0 \%$ 、動脈・門脈の走行に解剖学的変異を認めなかった。 2017年11月肝左葉グラフト採取術施行。術中 B $2 / 3$ の南回りの 走行が確認された。胆管切離に際し B $2 / 3$ と B 4 が二穴となっ たため、バックテーブルで北回り B 4 と一穴化した。この際、2 穴間に距離があったため B 4 を十分に剥離し門脈の狭窄を回避し つつ門脈の腹側で一穴化を行った。レシピエントの胆道再建は胆 管空腸吻合で行った。ドナー・レシピエントとも術後胆汁漏・胆 管狭窄なく、経過良好で退院された。結語】生体肝移植の実施 においてはドナー・レシピエント双方で術前ならびに術中に判明 した解剖により柔軟に術式を考える必要がある。

17 術後病理所見で判明した極めて稀な胆管癌肉腫の 1 切

除例

旭川医科大学 外科学講座 消化器病態外科学分野

水上奨一朗、高橋裕之、今井浩二、萩原正弘、金澤宽之、川原敏 靖、松野直徒、古川博之

【はじめに】癌肉腫は同一腫瘍内に癌腫部分と肉腫様部分とを併 せ持つ悪性腫瘍で、癌が発生するすべての臓器で発生するとされ ている。消化器系における癌肉腫のうち, 胆道系では胆囊での報 告がしばしば見られるものの肝外胆管に原発した文献報告は英文 邦文合わせて24例と極めて稀である。【症例】70歳代男性。顕性 黄疸のため当院内科を受診し腹部造影 $\mathrm{CT}$ を施行したところ遠位 胆管に結節性病変を認めた。入院精查し遠位胆管癌と診断、当科 で覀全胃温存膵頭十二指腸切除を施行した。病理診断は $\mathrm{pBd}$, circ, pT 2 a, sci, INFc, ly 0, v 1, ne 3 , pDM 0, pHM 0 , pEM 0, pN 0, pStageIB、腫瘍組織はクロマチンの増量した不 整の核をもつ紡釺形の異型細胞が個々バラバラに線維化を伴い胆 管壁全層に渡って浸潤しており、免疫染色でpancytokeratin 陽性 であり癌肉腫と診断された。現在術後 4 ケ月経過しているが無再 発生存中である。【考察】過去の報告では胆管癌肉腫の術前診断 は非常に困難で術前に胆管癌肉腫と診断されたものは 1 例のみで ある。治療としては根治切除可能なものは本症例と同様に膵頭 十二指腸切除が多く施行されているが、術後約半数に肝転移再発 が認められている。その予後は従来腫瘍浸潤部に肉腫様部分が見 られることが多く全身性転移をきたしやすいことから一般的な胆 管癌に比べ予後不良と考えられてきたが、近年の報告例のまとめ ではその 5 年生存率は $49.2 \%$ と一般的な胆管癌切除術後症例の 5 年生存率 $(33.1 \%)$ に比べむしろ良好の可能性があるとされてい る。本症例は膵頭十二指腸切除後の病理所見で胆管癌肉腫と診断 されたが、現在無再発で良好な経過をたどっている。【まとめ 胆管癌肉腫の症例は未だ稀少であり、本症例は症例集積のための 貴重な一切除例であった。

18 家族性地中海熱が疑われた 4 歳女览に胆石症が合併し た 1 例 旭川医科大学 小児外科 石井大介、宮城久之、平澤雅敏、宮本和俊 【はじめに】家族性地中海熱（FMF）とは，周期性発熱と漿膜炎 発作を特徵とする自己炎症性疾患である。【症例】 4 歳女児、 1 歳時より発熱と腹痛を伴う発作を 2 週から 4 週間隔で繰り返して いた。母にFMFの既往があり、患児も FMFが疑われ当院皮膚 科でフォロー中である。3 歳時にノロウイルス腸炎とインフルエ ンザで前医入院、入院中の画像検查で胆石症が指摘され、当科紹 介受診した。胆石は最大 $15 \mathrm{~mm}$ 大、発熱と腹痛の原因として胆石 
症も鑑別に挙がり、家族の希望もあり、腹腔鏡下胆囊摘出術を施 行した。術後経過は良好で、術後 1 か月現在、発熱や腹痛の発作 は見られていない。【考察】FMFと胆石症の関連は現在報告され ていないが、FMFは急性腹症との鑑別が困難となり、虫垂切除 や胆囊切除を受けた患者が多いとの報告はある。今回我々は FMFが疑われた女児に胆石症が合併した 1 例を経験したので、 文献的考察を加えて報告する。

19 進行胆管癌と術前診断したが術後摘出標本で浸潤癌を 認めなかった 2 例

北海道大学 消化器外科 II ${ }^{1}$ 、北海道大学病院 病理診断科 ${ }^{2}$

丹羽弘貴 ${ }^{1}$ 岡村圭祐 ${ }^{1}$ 、中西喜嗣 1 、浅野賢道 ${ }^{1}$ 、海老原裕磨 1 、倉 島 庸 ${ }^{1}$ 、野路武寛1、中村 透 1 村上壮一1、土川貴裕 1 、七戸俊明 1 、 三橋智子、平野 聡 1

【緒言】画像上の胆管狭窄および術前胆管生検結果と術後標本の 結果に乘離を認める例がある。今回、術前に狭窄を伴う進行胆管 癌と診断したが、術後病理検体上、狭窄部に浸潤癌を認めなかっ た 2 例を経験した。【症例 1】70代、女性。左肝管狭窄・左肝内 結石を指摘され、狭窄部からの生検で腺癌と判断した。肝門部胆 管癌の診断で肝左葉尾状葉切除・肝外胆管切除を施行したが、術 後病理組織診断では狭窄部にリンパ球浸潤を伴った軽度の線維性 肥厚像を認めたが、上皮に明らかな異型は認めなかった。症例 2】 70 代、男性。総胆管結石の診断で紹介受診した。膵内胆管の狭窄 像と同部位生検で腺癌を認め、遠位胆管癌と診断した。膵頭十二 指腸切除施行後の病理組織診断では、狭窄部に軽度の異型上皮と 一部、間質の線維増生を認めたが浸潤癌の所見はなかった。結語】 胆管狭窄病変の中には、生検を組み合わせても正診が困難な例が あることに留意すべきと考えられた。

\section{0 胆管空腸吻合部狭窄の現状}

手稲渓仁会病院 外科

高田 実、安保義恭、市丸千聖、原田裕輔、藤井正和、七里圭子、 西 智史、篠原良仁、武内慎太郎、今村清隆、渡邊祐介、加藤健 太郎、木ノ下義宏、中村文隆、樫村暢一

【背景と目的】胆管空腸吻合術を行った症例の合併症として吻合 部狭窄があげられる。吻合部狭窄疑いに対してShort type シン グルバルーン内視鏡（Short SBE）を行った症例を検討し、対策 についても考案する。【対象】2004年 1月～2016年12月までに行 われた胆管空腸吻合症例を検討し、吻合部狭窄の発生率、症状、 年次の推移、手術内容、胆管性状などを検討した。【結果】SSPPD485例中 22 例 $(4.5 \%)$ が診断され、肝切除＋胆管再建では 86 例中 6 例 $(7.0 \%)$ が診断された。発見契機は結石指摘10例、発 熱12例、胆道系酵素上昇 4 例などであった。吻合部狭窄が起こっ た胆管性状は、正常胆管22例、拡張胆管 3 例であった。【考察】 正常胆管に発生頻度が高く、正常胆管の吻合法に改善の余地があ ると考えた。現在は $6-0$ 吸収糸による吻合と、正常胆管にはス テントを必須とするなど工夫を行っている。
21 術後19年目に発見された膵Solid-pseudopapillary neoplasm 局所再発の 1 例

$\mathrm{JA}$ 北海道厚生連 旭川厚生病院 外科 1 、 $\mathrm{JA}$ 北海道厚生連 旭川厚 生病院 病理診断科 ${ }^{2}$

志智俊介 ${ }^{1}$ 、山田健司 ${ }^{1}$ 、紅露大介 ${ }^{1}$ 、佐野修平 1 、西越崇博 1 、腰塚 靖之 ${ }^{1}$ 、芝木泰一郎 ${ }^{1}$ 柳田尚之 ${ }^{1}$ 池上 淳 ${ }^{1}$ 稲垣光裕 ${ }^{1}$ 、佐藤啓介 ${ }^{2} 、$ 赤羽弘充 ${ }^{1}$

症例は79歳女性、19年前に膵Solid and cystic tumorに対し膵体 尾部切除術の手術歴があり、今回は腹部打撲を契機とした腹痛を 主訴に当院を受診した。精查で $23 \mathrm{~cm}$ 大の腹腔内腫瘤を指摘され、 胃GIST疑いとして手術目的に当科紹介となった。術中所見で腫 瘍は横隔膜、胃壁、肝臓への浸潤が疑われたため腫瘍摘出、胃 · 横隔膜部分切除、肝外側区切除術を施行した。病理結果で腫瘍は 前回手術の標本と類似する所見を示し、胃漿膜表面から突出して おり肝被膜や横隔膜に浸潤はなかった。免疫染色を施行し膵Solid-pseudopapillary neoplasm(膵 SPN) の局所再発と診断された。 膵SPNは比較的稀な低悪性度の膵腫瘍で、本邦における膵SPN の異時性再発は医中誌で検索して14例の報告（会議録を除く）が あり、肝転移 6 例、播種性局所再発 5 例、残膵再発 5 例で、その うち初回手術から再発までの期間で 10 年以上のものが 5 例あり、 長期経過を経て再発を認めることがあるため注意を要する。本症 例では初回病理で静脈侵襲があり過去の報告同様に悪性度に関与 する可能性が考えられた。また転移巣に関しても切除により良好 な予後が得られるとされる。今回我々は長期経過にて再発した膵 SPNの 1 例を経験したので報告する。

22 拳上空腸拡張症例から学ぶ膵頭十二指腸切除術におけ る Blumgart変法の適切な運針法の検討

愛育病院 外科

中山智英、山吹 匠

膵頭十二指腸切除術における Blumgart変法の利点は, 膵切離断 端と空腸壁の密な間隙閉鎖と, 膵実質刺入点での被膜損傷の少な さが挙げられるが, 膵実質刺入点の腸管壁による確実な被覆も利 点の一つである，そのため漿筋層を拾う幅が重要だが，時に空腸 内腔が狭くなる場合もある. 高度技能専門医取得後 $(2017 / 6$ ～ 2018/2）に施行したBlumgart変法 7 症例で, 術後 CTでの拳上 空腸拡張の有無を確認し, 膵管粘膜吻合位置や漿筋層の運針方法 について検討した. 拳上空腸拡張は 2 例に認め, いずれも術中に 腸管浮腫を認めていた。膵実質刺入点の確実な被覆を意識し, や や広めに漿筋層を拾う事を心がけているが, 浮腫で腸管壁が厚い 症例では漿筋層を拾う幅に注意する必要がある。また, 変法では 後壁（背側）の漿筋層は腸管長軸に沿って一針拾うのみであるた め, 膵管粘膜吻合の位置をやや後壁（背側）寄りに作成した方が, 腸管前壁 (腹側) で腸管短軸方向に拾う漿筋層の幅に余裕が生ま れると考えられた。

23 主膵管と交通を認めた膵 serous cystic neoplasm の 1 例 北海道大学大 学院医学院 · 医学研究院 消化器外科学教室 II 吉田雄亮、浅野賢道、木村弘太郎、関谷 翔、丹羽弘貴、城崎友 秀、横山新一郎、斎藤崇宏、水沼謙一、田中宏典、細井勇人、真 木健裕、山村喜之、中西喜嗣、野路武宽、海老原裕磨、倉島 庸、 村上壮一、中村 透、土川貴裕、岡村圭祐、七戸俊明、平野 聡 症例は30代、男性。検診のUSで膵体部に囊胞性病変を指摘され 当院に紹介となった。CTでは膵体部に一部隔壁に造影効果を伴 
う多房性囊胞性病変を認め、USでも膵体部に主膵管と連続する $38 \mathrm{~mm}$ 大の囊胞性病変の集簇を認めた。各種画像において主膵管 の拡張は認めなかった。以上より、分枝型膵管内乳頭粘液性腫瘍 (以下、IPMN) と診断し、膵中央切除を施行した。術後、 GradeBの膵液瘦を認めたがドレナージで改善し、第16病日に退 院となった。標本造影において囊胞と主膵管の交通を認めたが、 病理組織学的に漿液性囊胞腫瘍 (以下、SCN)、 olygocystic type と診断した。膵 SCNは一般的に主膵管との交通を認めない囊胞 性腫瘍とされるが、本例では主膵管との交通を認め、分枝型 IPMN との鑑別が困難であった。今回、非典型的な SCN の 1 例 を経験したので、文献的考察を加えて報告する。

\section{4 術前に診断に難渋した巨大膵漿液性囊胞腫瘍（SCN） の 1 例 \\ 札幌医科大学 消化器 - 総合、乳腺 · 内分泌外科}

藤野紘貴、今村将史、木村康利、吉田瑛司、永山 稔、信岡隆幸、 竹政伊知朗

【はじめに】Serous cystadenoma（SCN）は時に膨張性発育や周 囲への浸潤像を呈することがある比較的まれな脺囊胞性腫瘍で、 悪性疾患との鑑別が困難なことがある。【症例】60代、女性。造 影 CTで後腹膜腔を主座とする $15 \mathrm{~cm}$ 大の辺縁に造影効果を伴う 腫演があり、胃・膵臟・脾臓・左腎臓との境界が不明膫であった。 MRIでは内部がT 1 強調像で低信号、T 2 強調像でやや高信号で あった。脂肪肉腫などの後腹膜腫瘍のほか、膵腺房細胞癌や粘液 癌、SCNなどが鑑別として挙げられた。FNAでは組織診断に至 らなかった。【手術所見】腫瘍は膵被膜内に留まっており膵原発 の腫瘍が考えられ尾側膵切除術、D 2 を施行した。【病理所見】 摘出標本では小型囊胞が集簇した腫瘍であり、免疫組織化学所見 をふまえSCNの診断となった。【まとめ】本症例では術前に診断 の確定が困難であり、また膵尾部周囲の組織との浸潤が否定でき かった。術前に画像上鑑別が困難であった巨大 SCN の症例を経 験したので文献的考察を加えて報告する。

\section{5 乳頭内皮増殖を伴った脾リンパ管腫の 1 例}

$\mathrm{JA}$ 北海道厚生連 帯店厚生病院 外科

倉谷友崇、市之川正臣、桑原尚太、和田秀之、武藤 潤、加藤航 平、吉岡達也、村川力彦、池田 篤、松本 讓、大竹節之、大野 耕一

リンパ管腫は比較的稀な疾患であり、75\%は頸部、 $20 \%$ は腋窝に 見られ、脾臓は稀である。症例は56歳男性。2014年の当院健診の 腹部超音波検查で、脾臓内に $2.5 \mathrm{~cm}$ 大の腫瘤性病変を指摘された。 2017年11月の健診では腫瘤は $5.5 \mathrm{~cm}$ と増大傾向を認め、手術希望 もあり、2018年 1 月に当科にて腹胿鏡補助下脾臓摘出術を施行し た。摘出された腫瘍は $5.0 \times 4.5 \times 4.0 \mathrm{~cm}$ 大で中心部痏痕を伴う分葉 状腫瘍を認め、Splenic lymphangioma with papillary endotherial proliferationの病理診断であった。免疫染色では、CD31・ $\mathrm{CD} 34 \cdot \mathrm{ERG}$ ：陽性、D 2-40：極一部弱陽性、CD 8：陰性、 MIB-1 index：1％以下、P53：陰性であった。術後経過は良 好で、術後 8 日目に退院となった。術後 3 か月現在、無再発生存 中である。1939年以降の報告で乳頭状内皮増殖を伴った脾リンパ 管腫は数例しかなく、今回非常に稀な症例を経験したので文献的 考察を加え報告する。
26 腹腔鏡下脾部分切除術を施行し正常脾を温存した巨大 脾囊胞の一例

北海道大学 消化器外科 II

木村弘太郎、倉島 庸、中西喜嗣、浅野賢道、海老原裕磨、村上 壮一、中村 透、土川貴裕、岡村圭祐、七戸俊明、平野 聡 症例は 30 代、女性。心窩部痛を主訴に近医を受診し直径 $8 \mathrm{~cm}$ 大 の巨大脾囊胞を指摘された。症状を伴う巨大脾囊胞であるため外 科的切除の方針となった。術前の画像検查において囊胞は脾上極 に限局しており、患者が若年であることも考慮し、脾下極を温存 する腹望鏡下脾部分切除術を施行した。手術は左上肢挙上砕石位 によるCo-Axial アプローチで行った。手術手順は、まず脾動脈 本幹をテーピング確保したのち、脾動静脈上極枝をクランプしデ マルケーションラインを確認した。脾動静脈上極枝を自動縫合器 で切離した後、脾切離はバイポーラ電気凝固止血装置によるプレ 凝固およびベッセルシーリングシステムにより行った。切除脾は 下腹部横切開創より体外へ摘出した。手術時間は 3 時間 44 分で出 血は極少量であった。成人の巨大脾囊胞に対し、腹腔鏡下に脾部 分切除術を行うことは安全であり、整容面においても優れている ことから有用な選択肢の一つと考えられた。

27 腹染鏡下直腸高位前方切除術後に細径ポートサイトヘ ルニアを来した 1 例

釧路労災病院

坂本沙織、河合朋昭、笠原里紗、小林展大、石川隆壽、小林清二、 小笠原和宏

症例は77歳、男性。前医で貧血・便潜血陽性を指摘され、精查 目的に当院内科を紹介された。RS直腸がん（T３（SS） N 1 M 0 Stage III a) の診断で当科紹介、腹腔鏡下直腸高位前方切除術 （DST）を施行した。左下腹部 $5 \mathrm{~mm}$ 細径ポート創経由で $19 \mathrm{Fr}$ シ リコンドレインを挿入し吻合部後面に留置した。術後経過は順調 で術後 6 日目にドレインを抜去したが、翌日の定期レントゲン検 查でイレウス所見を認めたため絶食・補液で保存治療を開始した。 腹部に有意な所見は認めなかったものの、イレウスの改善がみら れず、術後15日目でCT検查を施行した。ドレイン抜去部の皮下 にポート創からの小腸脱出・嵌頓を認め、緊急手術を行った。腸 管壊死の所見はなく、癒着剥離とへルニア修復を施行した。

腹垫鏡手術の普及により、ポートサイトヘルニアの報告が増え つつある。細径ポートであっても嵌頓の可能性があり、術後イレ ウスの原因として考慮すべきである。

28 腹腔鏡下 Sugarbaker 法を施行後にメッシュ断裂によ り再発したストーマ傍へルニアの 1 例

札幌医科大学 消化器 - 総合、乳腺 - 内分泌外科

待木隆志、奥谷浩一、沖田憲司、西舘敏彦、碓井彰大、秋月恵美、 石井雅之、里吉哲太、小助川紗弥、竹政伊知朗

【はじめに】腹腔鏡下Sugarbaker 法を施行後に稀な再発形式をと ったストーマ傍へルニアを経験したので報告する。【症例】75歳 女性。直腸癌に対し腹腔鏡下直腸切断術を施行し、腹腔内経路で 結腸人工肛門を造設した。術後 2 年でストーマ傍へルニアを認め、 腹腔鏡下Sugarbaker 法を施行した。 3 年経過後に腹痛で救急搬 送され、CTでストーマ傍ヘルニア再発、消化管嵌頓の診断とな り緊急手術を行った。前回留置したメッシュの中央が断裂し 3 $\mathrm{cm}$ 大の欠損を認めた。嵌頓腸管は血流障害があり小腸部分切除 術を施行し、二期的に前回のメッシュを完全に被覆するように新 たなメッシュを留置した。【考察】Sugarbaker法の再発はメッシ 
工辺縁と挙上腸管が重なる部位の固定不良が原因との報告がある が、本例はメッシュの中心部が断裂しへルニア門となっていた。 初回修復術後から $10 \mathrm{~kg}$ の体重増加があり、メッシュ断裂の一因 と考えられた。

29 腹胿鏡下腹壁㾪痕へルニア修復術の周術期におけるア スピリン内服の安全性の検討

北海道消化器科病院 外科

上野 峰、蔦保暁生、桑谷俊彦、福島正之、田本英司、藤田美芳、 森田高行

近年，周術期のアスピリン内服を継続しても重大な出血性リスク の増加は認めず，休薬すると致命的な血栓性リスクが増したたこ とが報告され，欧米のガイドラインは，継続による出血性リスク が血栓性リスクを上回らないかぎり休薬しないことを推奨してい る. 腹腔鏡下腹壁㓔痕ヘルニア修復術（以下，LVHR）において は周術期のアスピリンの内服に関する検討は未だない，今回我々 は, LVHRの周術期におけるアスピリン内服の当科の経験から， その安全性を明らかにすることを目的とし検討を行った，症例は 2013年から2017年までに北海道消化器科病院外科で腹壁瘕痕へル ニアに対してLVHRを施行した40症例を対象とした。 アスピリ ン以外の抗凝固剤や抗血小板剂を内服・休薬していた 4 症例は除 外した。周術期にアスピリンを内服した $\mathrm{A}$ 群 $(\mathrm{n}=5)$ と未内服 あるいは休薬した $\mathrm{B}$ 群 $(\mathrm{n}=31)$ に分類し, 患者背景, 術中関連 因子 (手術時間, 出血量) - 術後の関連因子 (術後在院日数, 再 発の有無, その他の合併症）について比較検討した。結果は $\mathrm{A}$ 群と B 群では各因子に有意差は認めず, 全症例で出血性合併症, 血栓性・塞栓性の合併症も認めなかった，硬膜外麻酔に起因する 合併症も認めなかった．少数による検討ではあるもののLVHR の周術期のアスピリン使用による術中・術後の合併症は認めず, 安全に使用できる可能性が示唆された.

\section{0 子宮広間膜異常裂孔ヘルニアの 2 例}

深川市立病院

岡山大志、新居利英、水上周二

【症例 1】80代女性。腹腔鏡下マイルズ術後。腹痛、嘔吐を主訴 に受診。腹部造影 CTで絞扼性イレゥスと診断し同日緊急手術を 施行。術中所見で、Fenestra typeの子宮広間膜へルニアであり、 回腸が $40 \mathrm{~cm}$ ほど絞扼されていたが、腸管壊死はなく子宮円索の 切離のみ施行、対側にも同様の裂孔を認め子宮円索を切離した。 【症例 2】40代女性。帝王切開 2 回、子宮筋腫にて近医通院中で あった。腹痛を主訴に受診。腹部CTにて子宮周囲に絞扼性イレ ウスの所見あり、子宮広間膜へルニアを疑い同日緊急手術を施行 した。術中所見で、同様にFenestra typeであり、回腸が $50 \mathrm{~cm}$ 絞扼され腸管壊死を認めた。子宮円索の切離の後、小腸部分切除 を施行。子宮筋腫が大きく対側は確認できず。2 例とも術後卜ラ ブルなく退院された。子宮広間膜ヘルニアは子宮広間膜に生じた 異常裂孔に起因する内ヘルニアであり、比較的稀な疾患である。 今回我々は 2 例の手術を経験したので、若干の文献的考察を加え 報告する。
31 膵頭部嵌頓を伴った巨大食道裂孔ヘルニアの 1 例 $\mathrm{JA}$ 北海道厚生連 遠軽厚生病院 外科 1 、北榆会 札幌北榆病院 外 科 2 名寄市立総合病院 心臓血管外科 3

齋藤善也 1 後藤順一 ${ }^{1,2}$ 、浅井慶子 1 、岩田浩義 1,3 、北 健吾 1 、橋 本道紀 1 、稲葉 聡1 、矢吹英彦 1

はじめに：食道裂孔ヘルニアは一般的な疾患であるが、時に腹哚 内臓器の脱出、捻転等を伴うことがある。今回、膵頭部嵌頓を伴 った食道裂孔へルニアに対し手術を施行した症例を経験したので 報告する。

症例：71歳女性。突然の嘔気嘔吐を主訴に救急搬送された。 CT で胃の高度拡張、十二指腸や膵頭部、横行結腸の縦隔内脱出、 胆管拡張が認められた。血液検査では炎症反応上昇と肝胆道系酵 素の上昇を認め、胆汁うっ滞が示唆された。胃管挿入により症状 は軽快、再検 $\mathrm{CT}$ で膵頭部捻転の解除を認めた。入院 8 日目、待 機的に手術を施行した。

腹腔鏡下に腹腔内臓器を縦隔から腹腔内へ牽引、整復を試みたが ヘルニア門周囲の癒着が強く、開腹へ移行した。剥離後、ヘルニ ア門を縫縮、メッシュで再建した。手術後に一過性の胃内容物停 滞を認めたが、大きな合併症はなく術後30日目に退院となった。

今回は術中所見及び文献考察を含めて報告する。

32 腹会陰式直腸切断術後の会陰ヘルニアに対する腹胫鏡 か修復術の経験

手稲溪仁会病院 外科

市丸千聖、高田 実、原田裕輔、藤井正和、七里圭子、西 智史、 篠原良仁、今村清隆、渡邊祐介、武内慎太郎、加藤健太郎、木 下義宏、安保義恭、中村文隆、樫村暢一

腹会院式直腸切断術後の会陰へルニアの発生率は $1-13 \%$ と比較 的稀な合併症である. 今回, 腹会陰式直腸切断術後に発生した会 陰ヘルニアを 2 例経験したので報告する. 症例 1 は63歳の男性. 腹腔鏡下腹会院式直腸切断術施行後半年で会陰ヘルニアを発症 し，腹腔鏡下メッシュ修復術を行った。メッシュは骨盤底に全周 性に非吸収糸で縫合固定し会陰底を形成した。症例 2 は81歳の女 性, 腹腔鏡下腹会陰式直腸切断術後・化学療法後の会陰ヘルニア に対して, 同じく腹腔鏡下にメッシュを用いて修復術を行った. 前壁は膀胱を剥離の上クーパー䩲帯に, 後壁は仙骨に金属夕ッカ 一を使用して固定しさらに全周縫合を行った，会陰へルニアへの アプローチとして1）経会陰式，2）経腹式（開腹）， 3 ）腹脘 鏡下などが挙げられるが, 腹腔鏡下の利点は, 狭い骨盤腔におい て視野を得やすく, 且つ腹腔内から癒着剥離できる利点があり, 開腹と比較し低侵襲であることからも腹腔鏡下が有用であったと 推察される.

33 直接鼠径ヘルニアとの鑑別を要した再発間接鼠径ヘル ニアの一例

市立函館病院消化器外科 1 市立函館病院 乳腺外科 ${ }^{2}$

須藤亜希子、笠島浩行1、羽田光輝、正司裕隆、梅原 実1 植 木伸也 ${ }^{1}$ 佐藤利行 1 、久留島徾大 1 、鈴木伸作 2 、中西一彰1、木村 純 1

症例は70代男性。他院にて30年前に両側鼠径ヘルニアに対し手術 施行、 7 年前に再発右鼠径へルニアに対し再手術施行された既往 あり。再手術後より右鼠径部の膨隆あり、手術希望され当科紹介 受診。腹腔鏡下に鼠径部を観察したところ、右下腹壁動静脈内側 にヘルニア門を認め、右直接鼠径ヘルニア（II - 2 ） と診断、腹 腔鏡下右鼠径ヘルニア修復術（TEP）施行した。ヘルニア囊を 
末梢へ剥離したところ、ヘルニア囊と癒着する索状物の末梢に睪 丸が確認され、間接ヘルニア (I-2) と診断した。2 度の手術操 作により鼠径部の解剖が変化したため、下腹壁動静脈内側にヘル ニア門を有する間接へルニアを呈したと考えられた。再手術症例 においては、正常解剖からの逸脱を念頭におき、より詳細な術中 観察を要すると考えられた。

34 再発鼠径ヘルニアに腹腔鏡併用下での mesh plug 法が 有用であった 1 例

岩見沢市立総合病院 外科

南波宏征、阪田敏聖、柏倉さゆり、辻 健志、暮西弘規、谷 安 弘、羽田 力、上泉 洋、伊藤浩二

【初めに】両側鼠径ヘルニア根治術 7 年後の再発鼠径ヘルニアに 対して腹腔鏡併用下での mesh plug法が有用であった症例を経験 したため報告する。【症例】82歳、男性。75歳時に右鼠径ヘルニ ア根治術（ポリソフト法）を施行した。7 年後に右鼠径部膨隆を 自覚し当科受診、右鼠径へルニア再発の診断となった。ヘルニア 囊を確実に同定するため、腹腔鏡下で腹䏶内を観察した後、鼠径 部切開法を行う方針とした。手術所見としては腹腔内から内鼠径 型の再発を確認し、mesh plug法にてへルニア根治術を施行し手 術終了した。術後経過は良好で、第 3 病日に退院した。【考察】 再発鼠径ヘルニア例では鼠径管内の癒着によりヘルニア囊の同定 が困難な場合がある。今回の症例でも腹䏶併用下での鼠径部切開 法を行うことでヘルニア囊を確実に同定することができ、安全に ヘルニア根治術を施行する事が可能であった。【結語】再発鼠径 ヘルニアに腹腔鏡併用下での mesh plug 法は有用と考える。

\section{5 鼠径ヘルニア嵌頓症例に対する当院の治療戦略 製鉄記念室蘭病院 \\ 伊野永隼}

背景: 鼠径部ヘルニア嵌頓に対する腹望鏡下手術 (TAPP) は、徐々 に施行されつつある。当院では嵌頓症例のうち腸管拡張が弱く、 前立腺手術歴のない症例にTAPPを選択している。我々は当院 で施行した鼠径部ヘルニア嵌頓症例を検討し、結果を報告する。 方法 : 2015年 4 月から 2018 年 3 月まで、鼠径部ヘルニア陥頓に対 して手術を行った症例の術式、手術成績、治療結果について検討 した。結果：21例に手術を施行。TAPP15例（内 2 例は鼠径部切 開法に移行)、鼠径部切開法 6 例であった。手術時間の中央值は TAPPが98分、鼠径部切開法が82分、腸管切除を伴ったのは 4 例 （腹臆鏡 2 例、鼠径法 2 例）であった。合併症はTAPPでイレゥ スを 3 例認め、いずれも Clavien-Dindo分類（以下 CL）ＩI。鼠 径部切開法で創感染を 3 例認め、いずれもCL II であった。結論 : 術中合併症はいずれの治療法でも認めず、術後合併症はTAPP にてCL II 以上の合併症は認めなかった。

36 営径ヘルニア嵌頓に対する嵌頓解除後に再嵌頓に至っ た 1 例 北海道社会事業協会函館病院 外科 渡久山晃、河野 剛、久木田和晴、長谷川格 症例は59歳、男性。左鼠径部の膨隆・疼痛を主訴に当科受診され た。CTにてS 状結腸の脱出を認め用手還納は不能であり、嵌頓 ヘルニアと診断した。同日緊急手術を施行し、腹腔鏡下に観察し 左間接単径ヘルニアを認めた。ヘルニア門にはS 状結腸が嵌入し ており、嵌頓を解除した。腸管壊死は認めなかったが、少量の污 染腹水が貯留していたためメッシュによる修復は施行せず、後日
二期的に根治術を施行する方針とし手術を終了した。根治術の日 程を決定し術後 10 日目に一時退院したが、その翌日に再度 $\mathrm{S}$ 状結 腸の嵌頓を認め当科受診された。用手還納は不能であり、緊急手 術を施行した。再嵌頓症例のため腸管壊死の有無に関わらず根治 術の必要があると判断し、単径部切開法にてアプローチした。腸 管壊死および污染腹水の貯留を認めず、mesh plug法を施行した。 根治術を施行する時期に関して検討の余地があると思われる 1 例 を経験したため、若干の文献的考察を加え報告する。

37 腹腔鏡下手術で治療した急性虫垂炎合併Amyand's herniaの一例

富良野協会病院 外科

安達雄輝、藤原康博、渡邊賢二、松下和香子

虫垂が内容物となる鼠径へルニアはAmyand's hernia と呼ば れ、比較的稀な疾患である。急性虫垂炎を合併した場合の治療法 について、明確な指針は存在しない。今回われわれは腹腔鏡下手 術で治療し、良好な経過を得た一例を経験したので報告する。症 例は20歳代男性。前日から続く右下腹部痛と発熱を主訴に受診し た。血液検查では白血球と CRP の軽度上昇を認めた。CT 検查で 腫大した虫垂が鼠径管内に陥入している所見が得られ、急性虫垂 炎合併の Amyand's herniaの診断に至った。同日に腹腔鏡下手術 を行った。術前診断の通り、虫垂が内鼠径輪に陥入している状態 が確認された。亦引により露出された虫垂の末端は暗赤色に変色 しており、虫垂壊死が想定されたため、腹胿鏡下で虫垂切除と内 鼠径輪縫縮を行った。術後 6 ケ月時点では、ヘルニアの再発や合 併症の出現はなく経過している。Amyand's herniaに対し、腹腔 鏡下手術が治療の選択肢となり得る可能性が示唆された。

38 乳癌に対する Eribulin使用例の検討

札幌ことに乳腺クリニック1、北海道千歳リハビリテーション大 学 $^{2}$

増岡秀次 ${ }^{1} 、$ 三神俊彦1、下川原出 ${ }^{1} 、$ 浅石和昭 ${ }^{1} 、$ 森 満 ${ }^{2}$

【はじめに】転移・再発乳癌でアンスラサイクリン、タキサン系 薬の治療歴を有するErubulinの投与はOSの延長を示唆されてい る。【目的】 Eribulin使用例を後方視的に検討する。特に肝転移 について検討する。【対象および方法】2013年以降再発乳癌に Eribulin を37例に投与した。倦急感、末梢神経障害、骨髄抑制等 の副作用にて投与中止の 5 例を除く 32 例を後方視的な解析の対象 とした。年齢は 43 歳から 77 歳、平均 54.5 歳である。平均投与期間 は5.1か月（50\% TTPは5.4か月）である。予後はKaplan-Meier 法にて求め、検定はLogrank（Mantel-Cox）を用いた。【結果お よび考察】ほとんどがvisceralで $90 \%$ 占める。前化学療法レジ メン数は3.3剤、レジメンは多い順にFEC, DTX, VNRであった。 Eribulin投与終了後の OS は平均11.1か月であった。前投与レジメ ン数の比較では、 2 レジメン、 3 レジメン以下では $50 \%$ TTPは 11.5 か月、 7.0 かと有意を持って上昇した $(\mathrm{p}=0.275$, $\mathrm{p}=0.0246)$ 。 up frontでの使用が勧められる。また肝転移は18例 に認められ、肝転移単独例の $50 \%$ TTP は8.5か月で、投与終了後 のOSは約28か月で、OSの延長も認められた。しかし CR 例はな かった。【とめ】 Eribulin投与例の50\% TTPは5.4か月。投与終 了後の $50 \%$ OSは 10.9 か月。他の抗癌剂同様、早い使用、特に 3 レジメンまでの使用が勧められる。肝転移には効果がある可能性 があるかもしれないが、予後は不良である。肝の単独転移には効 果が期待できそうである。しかし肝転移を含む他臓器転移には効 果は不良と示唆される。今後 $\mathrm{CDK} 4 / 6$ 阻害剤等の後治療として も期待される。 


\section{9 糖尿病性乳腺症の 1 例}

旭川医科大学 乳腺疾患センター1、旭川医科大学病院 手術部2 安田俊輔 ${ }^{1}$ 高橋奈七 ${ }^{1}$ 、岡崎 智1 、石橋 佳 $^{1}$ 、北田正博1、平田 哲 ${ }^{2}$

はじめに：糖尿病性乳腺症（Diabetic Mastopathy）は, 1 型, 2 型糖尿病患者に認められる特殊な乳腺症であり, 比較的稀な疾 患である. 通常, 無痛性の乳腺腫瘍で発見され, 病理組織学的に は乳腺の高度な繊維化, または小葉, 乳管, 血管周囲のリンパ球 浸潤を特徵とする乳腺炎を主とする良性疾患である. 乳癌との鑑 別が重要であるが, 画像診断の領域ではマンモグラフィ（MMG） や乳腺エコーでの鑑別は困難であり, 造影 MRIや造影 CTが有用 とされる。

症例：64歳, 女性. 右乳房の腫瘍を主訴に前医を受診した. 併存 疾患として 2 型糖尿病, 脂質異常症を有していた. MMGでは $\mathrm{R}-\mathrm{M} / \mathrm{O}$ に $\mathrm{FAD}$ を認めカテゴリー3，乳腺エコーでは径 $2.5 \mathrm{~cm}$, 円形, 辺縁明瞭粗造, 前方境界線断裂を認めず, 内部エコーは均 一な低エコー, 後方エコーは減弱を示し, カテゴリー 3 の診断で あり悪性も疑われた．穿刺吸引細胞診が施行されたが検体不適と なり，精查加療目的に当科紹介となった。造影MRIで漸増性の 非腫瘤性増強効果およびT 2 WIで低信号を呈し，糖尿病性乳腺 症が疑われた，針生検ではびまん性の線維化のみ認めた。確定診 断目的に乳腺腫瘍摘出術を施行し, 糖尿病性乳腺症の診断となっ た．若干の文献的考察を加え，報告する。

40 主幹静脈の広範閉塞を伴う透析 ASO 症例に対する治 療経験

医療法人元生会 森山病院 血管外科

稲葉雅史

【症例】65歳女性。【主訴】両足趾壊死、疼痛【既往歴】 2 型糖尿 病、脳梗塞、慢性腎不全（血液透析）【現病歴】2018.1に鞉擦れ により足趾に潰瘍出現し、感染を伴い疼痛が増強したため当科紹 介となった。両下肢ともに足部動脈触知できず ABIは測定不能 で、SPP值は両側とも低值であった。透析用内シャントが左大腿 部に移植されており、両上肢、前胸部、鼠径部には内シャント作 成に伴う創が存在した。【手術】血行再建に先立ち中心静脈ルー 卜確保が必要であったが、画側内頸静脈、鎖骨下静脈掞よび腸骨・ 大腿静脈には閉塞あるいは狭小化が認められた。このため上腕部 を皮膚切開し静脈剥離、カットダウンの後ガイドワイヤーを併用 しX線透視下にカテーテルを至適部位に誘導した。術前造影所見 や静脈不足から内径 $6 \mathrm{~mm}$ の人工血管による大腿一膝上膝窩動脈 バイパスを両下肢に異時的に行った。術後 2 か月で内シャント修 復、静脈注入用ポート移植を行い経過観察している。

41 止血縫合デバイスを用い経皮的穿刺で施行したステン トグラフト内拌術の一例

旭川医科大学 血管外科

鎌田啓輔、竜川貴光、栗山直也、栃寉 藍、菊地信介、内田大貴、 古屋敦宏、東 信良

86歳, 男性. $60 \mathrm{~mm}$ の腹部大動脈瘤で紹介. COPDでHOT中で, 全身麻酔を回避し局所麻酔下に総大腿動脈穿刺でのSG 留置を選 択. 穿刺部の止血縫合のためパークローズ PROGLIDE ${ }^{\circledR}$ (PRG) による preclosing technique（PCT）を用いた，解剖形態で中枢 ネックが水平に近い高度屈曲を認めAorfix を選択. PCTの手技 は，まず18G外套針で総大腿動脈を穿刺し，0.035ガイドワイヤー （GW）を進め, これをガイドに1本目のPRGの糸を10時方向に
掛け, $\mathrm{GW}$ を残してさらに 2 本目の PRGを通し, 糸を 2 時方向 に掛け，2本の糸が交差するように掛ける。，その後, 右鼠径から メインボディを挿入し, 腎動脈直下に展開し, 脚は両側とも総腸 骨動脈に留置した。最終造影後, 刺入部を圧迫しながらシースを 抜去し，あらかじめ掛けた縫合系で刺入部を結紮閉鎖. 術後の造 影CTで動脈穿刺箇所には異常を認めなかったが, Type I aエン ドリークを認め, 同様の穿刺手技で中枢カフ追加を実施できた。 また，止血に要す時間も短縮可能であった.

\section{2}

上腕尺側一橈側連続皮静脈グラフトによる末梢バイパ 久症例

製鉄記念室蘭病院 心臟血管外科 1 、旭川医科大学外科学講座 血管· 呼吸・腫瘍病態外科学分野血管外科学分野 2

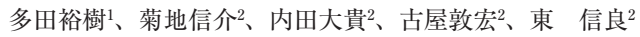

上腕尺側一橈側皮静脈の連続採取によるグラフトで末梢バイパス を実施した。これは先行文献でBasilic-cephalic loop graftとして 報告されており、メリットとして上腕の比較的大口径の静脈を長 い single segmentとして用いる事ができる。症例は51歳男性。糖 尿病、高度心機能低下 $(\mathrm{EF} 17 \%$ )、維持透析症例。左下肢重症虚 血（Rutherford-IV) に対し、同側大伏在静脈を用いた総大腿— 膝下膝窩動脈バイパスを実施されている。宿主末梢動脈病変進行 でグラフト閉塞し、足趾潰瘍で虚血再燃。対側下肢も大伏在静脈 を用いたバイパス施行後で、利用可能な静脈は右上肢静脈または 両側小伏在静脈のみであった。右上腕尺側一橈側皮静脈を連続採 取し、大腿一後脛骨動脈バイパスを施行した。術後下肢の虚血症 状は軽快した。術後 7 か月後のグラフト吻合部修復時の造影では、 グラフト本体部に狭窄は認めなかった。

43 微小塞栓による両下肢痛を契機に発見された腹部大動 脈瘤の 1 例

名寄市立総合病院 心臓血管外科

岩田浩義、清水紀之、真岸克明、和泉裕一

微小塞栓による両下肢痛を契機に発見された腹部大動脈瘤の 1 例 を経験したので報告する，症例は65歳，男性．前日から持続する 両下肢痛と歩行困難を主訴に, 近医整形外科を受診した。CTで 最大径 $74 \mathrm{~mm}$ の壁在血栓を伴う腹部大動脈瘤を認めたため, 当院 へ搬送となった，腹部から両下肢にかけて網状紫斑が存在し，両 大腿動脈以下の動脈は触知できたが, 両下腿の把握痛と両足趾の 自発痛を認めた，腹部大動脈瘤壁在血栓による両下肢の微小塞栓 症が疑われた。破裂や塞栓症続発の危険性を考慮し, 緊急で腹部 大動脈ステントグラフト内挿術を施行した。術後のMNMSは回 避でき, CKは13,088 IU/Lまで上昇したが, その後peak outし, 両下肢の紫斑も消退した，術後CTで endoleakを認めず，経過良 好で退院とした。

44 食道胃接合部粘膜下腫瘍に対するLaparoscopy and Endoscopy Cooperative Surgery（LECS）の一例

市立旭川病院 外科

本谷康二

【背景・目的】食道の粘膜下腫瘍（SMT）は平滑筋腫などの良性 疾患が多くを占めるため、リンパ節郭清が不要であり、より低侵 襲な術式が求められる。今回、食道胃接合部に発生したSMTに 対して、腹望鏡内視鏡合同手術（LECS）を施行した一例を経験 した。【症例】40歳の男性。ドック健診の上部消化管内視鏡検查 にて食道胃接合部に $30 \mathrm{~mm}$ 大のSMTを認め、EUSにて固有筋層 
からの発生している所見であり平滑筋腫の診断となった。手術は まず腹哚鏡下で食道周囲の剥離を行った後に、内視鏡下に腫瘍周 囲を全周性にマーキングし、腫瘍の最口側から粘膜の切開・剥離 を施行した。約半周程度剥離した後に、腫瘍の最肛門側で意図的 に腹腔内へ穿孔させ、同部位からマーキングに沿って腹腔鏡下に 超音波切開装置にて切離し腫瘍を摘出した。切除部位は手綘いに より縫合閉鎖した。組織学的診断では平滑筋腫の診断であり、断 端は陰性であった。術後 5 ケ月現在、狭窄等の合併症なく経過し ている。

45 膵体尾部切除後の幽門側胃切除で残胃血流評価に術中 ICG 蛍光造影法を用いた一例

札幌医科大学 消化器 - 総合、乳腺 $\cdot$ 内分泌外科

金澤あゆみ、伊東竜哉、信岡隆幸、村上武志、今村将史、木村康 利、竹政伊知朗

【はじめに】膵体尾部切除 (DP) 後の幽門側胃切除 (DG) は、 残胃に血流低下が生じる可能性がある。今回我々は、ICG 蛍光造 影法を用いて残胃血流を評価し、DP後のDGを行い得た一例を 経験したので報告する。【症例提示】70代男性。膵尾部癌（T $3 \mathrm{~N}$ 0 M 0 Stage II A) に対してDPを施行し、 2 年後に前庭部胃癌 (T $1 \mathrm{aN} 0$ M 0 StageIA）と診断され、腹腔鏡下幽門側胃切除術、D $1+$ 郭清を施行した。胃切離の前後でICGを静注し、残胃の血流 が維持されていることを確認した。残胃炎や縫合不全無く経過し、 術後11日で退院した。【考察】術中ICG 蛍光造影法は臓器血流を 客観的に評価できる方法として有用である。本症例でも同手法に より残胃血流の評価を行ったことで、安全にDGを行えた。結語】 DP後のDGにおける残胃血流評価において、ICG 蛍光造影法が 有用である可能性が示唆された。

46 胃癌胃全摘後の十二指腸断端再発および虫垂転移に対 して胆管空腸吻合、回盲部切除術を施行した 1 例 独立行政法人地域医療機能推進機構札幌北辰病院 外科

矢部沙織、奥村一慶、下國達志、中川隆公、西川 眞、高橋昌宏 【症例】 82歳、男性【既往歴】2 型糖尿病、高血圧、脂質異常【現 病歴】78歳時、胃癌に対して胃全摘術、D 2 郭清、Roux-Y再建、 胆囊摘出術を施行。病理所見は L, Less, type 3, muc $>$ tub 1 , pT 4 a, int, INFc, ly 2, v 1, pN 3 b, cM 0, pPM 0, pDM 0 , pStage 3 Cで, 術後補助化学療法は行わず再発なく経過していた。 術後 3 年 6 か月の 82 歳時、右下腹部痛を主訴に受診された。【身 体所見】Mcburney点を最強とする腹部全体の圧痛および腹膜刺 激症状を認めた。【画像所見】造影 CTでは、虫垂は腫大し壁肥 厚を認め、同時に肝内胆管の軽度拡張および膵頭部の腫瘤影およ び遠位胆管狭窄を認めた。急性虫垂炎および十二指腸断端再発も しくは胆管癌が疑われ、急性虫垂炎に対して保存加療が開始され た。炎症所見の遷延および腹部症状の増悪を認め、第 9 病日に造 影 CTを再検したところ、肝内胆管拡張の増悪および回盲部膿瘍 形成を認めた。急性虫垂炎穿孔膿瘍形成および十二指腸断端再発 の診断でdouble Roux-Y再建による胆管空腸吻合、回盲部切除 術を施行した。【病理所見】回盲部は粘膜下を首座とする白色調 変化を認め、虫垂粘膜の炎症は認めなかった。免疫染色で既往の 胃癌と同様の形質を示し、虫垂転移の診断となった。術後はDIC をきたしたが保存的加療により軽快し、術後17日目に退院となっ た。【結語】胃癌術後の消化管再発に対しては外科的介入が困難 な場合もあるが、手術治療が考慮され得る場合もある。
47 術前診断した胃神経鞘腫の 1 切除例

$\mathrm{JA}$ 北海道厚生連 札棍厚生病院 外科

田中友香、高橋周作、大野陽介、乾野幸子、船越 徹、山上英樹、 石津寛之

症例は41歳女性。心窩部痛にて近医受診。精査の結果、総胆管結 石疑いにて当院消化器内科紹介。保存的療法にて改善し今後胆囊 摘出術の方針となった。術前精查として上部消化管内視鏡検查を 行い胃体上部大弯に粘膜下腫瘍を認めた。超音波内視鏡検查では 中心に陥凹を伴っており陥凹面は第 4 層まで達しており潰瘍と判 断、27.5 $\times 20.2 \mathrm{~mm}$ 大の第 4 層に連続する低エコーmass、内部は 不均一でGISTが疑われたが、超音波内視鏡下生検で神経鞘腫の 診断となった。腹腔鏡下胃局所切除術、胆囊摘出術を施行。病理 結果はS-100蛋白陽性, c-kit, a SMA, CD34, Desmin陰性, Ki-67 labeling index $<1 \%$ \%あり良性神経䩗腫の診断に至った。 術後 3 年経過し、再発は認めていない。胃神経鞘腫は全胃腫瘍の 0.1- $0.2 \%$ と比較的稀な疾患で、画像診断のみではGISTや筋原性 腫瘍との鑑別が困難である。生検を行っても術前診断がついたも のは約 $6 \%$ と少ない。今回術前診断し腹腔鏡下手術を行った胃神経 鞘腫瘍の 1 例を経験したので若干の文献的考察を含めて報告する。

\section{8} 術前診断しえた十二指腸㮩室内結石による後腹膜穿通 の 1 例 旭川赤十字病院 外科

東嶋宏泰、平 康二、真名瀬博人、市村龍之助、蔵前太郎、西上 耕平、高野博信

症例は82歳、女性。某日昼食後から背部痛・右下腹部痛・嘔気を 自覚し当院救急搬送された。造影 CT で傍十二指腸乳頭媳室およ び憩室内結石を認め、慗室の背側/頭側から後腹膜腔に airが連 続し周囲脂肪織の濃度上昇と少量液体貯留を伴っており、後腹膜 穿通と診断し緊急開腹手術を施行。術中所見では十二指腸壁が菲 薄化しており不全穿孔抢よび㮩室内部に結石を認めたため、十二 指腸悡室縫合閉鎖・胆囊摘出術・隇圧目的にC-tube および十二 指腸隇圧チューブ留置・腸瘦造設を施行した。術後経過問題なく、 術後17日目に退院となった。

十二指腸傍乳頭悡室穿孔に関する本邦での症例報告は少なく治療 法も多様である。

本症例では緊急開腹手術で良い結果を得られたので、文献的考察 も加え報告する。

49 臨床工学技士のスコピストとしての手術参加 釧路日赤病院 外科 ${ }^{1}$ 釧路日赤病院医療技術部 臨床工学課 ${ }^{2}$ 安孫子剛大 1 、藤井康矢 1 、近江 亮 1 、猪俣 斉 1 、三栖賢次郎1、 金古裕之 1 、三井 潤1、齊藤貴浩 2 、三島諒祐 2 、佐久間寛2、章 純樹 2

[背景] 外科医の数は減少傾向であり、毎日の業務に人手が足り ないと感じる場面は多い。このような状況のなか、2012年日本臨 床工学技士会より“臨床工学技士の清潔野での補助業務”につい て記載された手術室業務指針が発表された。当院では2017年10月 より臨床工学技士のスコピストを導入している。[目的] 臨床工 学技士のスコピスト参加前後の症例で、手術時間・出血量・合併 症の有無について比較し、その妥当性を検討する。[結果] 卒後 13年目の外科医師が執刀した14例において、手術時間の延長や出 血量の増加など負の影響は認めなかった。また、卒後 3 年目の外 科医師が執刀した 8 例においても負の影響は認めなかった。術後 合併症は認めなかった。[考察] 臨床工学技士がスコピストとし 
て手術に参加することでの負の影響は認めなかった。臨床工学技 士としての業務を圧迫することが無い限り、業務削滅の観点から は有用である。

\section{0 当院における消化器外科領域でのロボット支援下手術 の現状} 恵佑会札幌病院 消化器外科

北上英彦、大川裕貴、山田 徹、坂下啓太、澄川宗祐、吉川智宏、 佐々木邦明、山口晃司、久須美貴哉、西田靖仙、細川正夫

当院では, ロボット支援下胃切除術を昨年12月より開始し, 本年 2 月までに 6 例を行った。本年 4 月の保険改正により当院は施設 基準を満たしており，4月にロボット支援下による胃全摘術，幽 門側胃切除術をそれぞれ 1 例ずつ保険適応下におこなった，今後 も症例数を増やしていく予定である. また, 食道癌手術, 直腸癌 手術にも保険適応となる施設基準を満たすため準備中である。今 回, 当院でのロボット支援下手術の現状, その実際, 保険適応下 のコスト面などの問題点を報告する.

\section{1 当院における腹腔鏡下幽門祖側胃切除術のART吻合 の経験}

\section{恵佑会札幌病院 外科}

坂下啓太、西田靖仙、北上英彦、大川裕貴、山田 徹、澄川宗祐、 山口晃司、吉川智宏、佐々木邦明、久須美貴哉、細川正夫

ART (Augmented Rectangle Technique) 吻合は、腹腔鏡下幽 門側胃切除術において福永らが提唱したBillroth I 法再建法であ る。その特徴として、1.四角吻合、 2 .大きな吻合口、3.真の端々 吻合、4.虚血域がない、 5 .支持糸がいらない、6.簡便であるこ となどがあるとされる。当院では2015年10月に導入し、2018年 3 月まで、158例の ART吻合を経験した。吻合時間（吻合の staple を腹腔内に挿入してから、吻合終了までの時間）は抄よそ 5 分で あり、主な合併症は縫合不全3.8\%（6 例/158例)、吻合部狭窄6.8 \%（10例/158例）であった。吻合部狭窄は導入当初が多く、手 技の安定により、減少する傾向を認めた。手術の実際を動画で共 覧し報告する。

\section{2 当院における腹腔鏡下噴門側胃切除術の初期成績} 市立旭川病院 外科

阿部紘丈、村上慶洋、窪田武哲、本谷康二、福永亮朗、笹村裕二、 武山 聡、子野日政昭

【背景】近年、手術手技の定型化ならびに再建方法の工夫から、 胃体上部の早期癌に対し、腹腔鏡下噴門側胃切除術（LPG）が施 行されることが増えてきている。当院でも2017年より体上部の早 期胃癌に対しLPGを導入したので、その手術成績並びに術後の 短期成績について検討し報告する。

【対象】2017年 1 月から2018年 3 月までに当院において LPGを施 行した 8 例。

【結果】症例の内訳は男性 7 例、女性 1 例。年齢の中央值は68歳

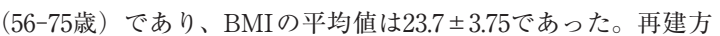
法は全例でダブルトラクト法を施行した。平均手術時間は $278 \pm$ 39分であった。術後は平均 2 日で水分を開始し、4.38日目には食 事を開始出来ていた。術後平均在院日数は $10.5 \pm 2.3$ 日であり、 Clavien-Dindo 分類 Grade 2 以上の合併症は認められなかった。 【考察】当院において導入後現在までに施行されたLPG症例を後 ろ向きに検討し、安全に導入できていた。今後さらなる症例の蓄 積を重ね、長期成績についても検討が必要である。
53 腹胿鏡補助下に後方骨盤内藏全摘と回盲部切除を施行 した腹膜癌の 1 例

市立函館病院 消化器外科

笠島浩行、須藤亜希子、正司裕隆、梅原 実、植木伸也、佐藤利 行、久留島徹大、鈴木伸作、中西一彰、木村 純 症例は56歳の女性. 既往に子宮頸部円錐切除. 平成 30 年 1 月, 子 宮がん検診で組織由来不明の悪性細胞が検出されたが, 紹介医婦 人科での US・臸鏡診で異常を認めず，腹部 CTで直腸腫瘍を指 摘され当院紹介となった. CTでは直腸壁や骨盤壁に沿って多数 の軟部腫瘤を認めるが, 子宮体部や卵巣には明らかな異常を認め なかった，大腸内視鏡では直腸 $\mathrm{S}$ 状部にSMT様の半周性腫瘍を 認めたが生検ではGroup 1 で診断に至らなかった。鑑別診断とし て腹膜播種伴う婦人科癌か特殊型の直腸癌か腹膜癌を念頭に当科 にて腹胿鏡下手術を行った．腹腔鏡所見では骨盤内に腹膜播種と 思われる腫瘍が広範囲に存在し，主たる腫瘍は直腸子宮窝に存在 していた，後方骨盤内臓全摘と回盲部切除で摘出可能と判断し, 両側尿管を確認温存しつつ腹腔鏡操作で直腸後腔の剥離を腫瘍よ り肛側まで行い, 必要な操作を腹䏕内で終えた後に下腹部に小切 開をおいて臟器を摘出した，病理組織診断では主として直腸と小 腸の粘膜下から腹膜に未分化癌の腫瘍増殖が見られ, 子宮の漿膜, 卵巣にも腫瘍が見られたが発育形態から卵巣癌は否定された。免 疫組織化学ではCK $7(+)$, CK19 (-), CK20 (-), AE $1 / \mathrm{AE}$ $3(+)$, CAM5.2 (+), Vimentin一部細胞陽性, Mesothelin (+) であり, いわゆる腹膜癌の診断となった。術後は当院婦人科で化 学療法を施行しており現在まで再発を認めていない。今回, 手術 ビデオを供覧すると共に，この疾患について若干の文献的考察を 踏まえて報告する。

\section{4}

肝細胞癌大腸転移と腺癌が混在した上行結腸癌の一切

除例

北海道大学大学院医学研究院 消化器外科学教室 I

田仲大樹、本間重紀、吉田 雅、市川伸樹、川俣 太、柴崎 晋、 川村秀樹、武冨紹信

症例は41歳, 男性. 5 歳時にWilims 腫瘍で右腎の摘出と化学療法. 放射線治療を施行されていた. 38歳時に閉塞性黄疸を契機に肝細 胞癌（T 3 N 0 M 0, Stage III）に対し, 当科にて肝右葉切除を 施行した。術後も AFPは高值であったため, 術後 2 年目に FDG-PET/CTを再検し，上行結腸に異常集積を認めた。下部消 化管内視鏡検查にて, 上行結腸に 2 型病変を認め、生検では Group 5, 高分化型管状腺癌であった. 上行結腸癌 ( T 3 N 0 M 0 , Stage II ) と診断し, 開腹右半結腸切除（D 3 ）を施行した. 術 後の病理組織検查では異形上皮細胞と類円形異形細胞の混在し, 免疫染色でそれぞれ腺癌と肝細胞癌大腸転移と診断した。また, 明らかなリンパ節転移は認めないものの, リンパ節周囲の脂肪織 内に肝細胞癌の転移巣を認めた。今回われわれは極めて稀な同一 腫瘍内に肝細胞癌の大腸転移と腺癌の混在する症例を経験したの で文献的考察を加え報告する。

55 当院における閉塞性大腸癌に対する bridging to surgeryとしての大腸ステント留置の検討

$\mathrm{JCHO}$ 北海道病院 外科

吉田祐一、正村裕紀、原田拓哉、敦賀陽介、数井啓蔵 大腸ステントは閉塞性大腸癌の緊急手術を回避する bridge to surgery（BTS）の手段として普及しつつある. 当院において 2013年 1 月から 2017 年12月までの間にBTS目的に大腸ステント 
を留置した21例を対象にその有用性を検討した． 年齢は平均71.6 （52～89）歳, 男性11例, 女性10例. 留置部位はS 状結腸が10例, 直腸 Rs 部が 7 例, 下行結腸が 2 例, 横行結腸が 2 例, 留置期間 は平均15日, 術式としては吻合部近傍に腹膜播種を認めたものと, 多発転移があり術後可及的に化学療法の方針となった 2 例を除い ては全例一期的吻合が可能であった，平均手術時間は205分, 平 均出血量は $129 \mathrm{ml}$, 平均術後在院日数は 19.9 日であり, 腹腔鏡手 術を $57 \%$ に施行した. 術後合併症は綘合不全を 2 例, 麻疩性イレ ウスを 1 例, 創部感染を 2 例認めた，閉塞性大腸癌に対してステ ント留置は安全な術前減圧と一期的吻合の可能性が高くなり人工 肛門造設のリスクを回避でき，有用と思われた。

56 臍転移を伴った横行結腸癌の 1 例

時計台記念病院 外科・腫瘍治療センター1、北海道大学 消化器外 科 II $^{2}$

青木貴徳 1 岡村幹郎1、梅本一史 2 、野路武寛 2 、平野 聡 2

【はじめに】悪性腫瘍の臍転移、Sister Mary Joseph's noduleは 予後不良な兆候とされる。今回臍部の転移で発症した横行結腸癌 の症例を経験した。【症例】41歳、女性。当院初診 3 ケ月前に臍 部の腫瘤に気づく。近医形成外科クリニックを受診し軟膏などの 処方にて経過観察されていた。改善せず当院形成外科を経由して、 当科へ紹介となった。単純 CTで1.5cm大の腫瘤が指摘された。腫 瘍と考え内視鏡検查、造影 $\mathrm{CT}$ 検査を锄めるも一切を拒否された。 本人の意向に沿い、当科初診から 1 ケ月後に臍部の腫瘤切除を行 った。病理で分化型管状腺癌とされた。本人、家族を説得し造影 CT、上・下部消化管内視鏡㭘查、PET 検査を行い、横行結腸癌、 多発肝転移、腹膜播種、子宮転移の疑いと診断した。全身化学療 法を導入し現在 SDを保っている。【結語】臍腫瘤は転移性を一 番に考える必要があり、全身検索が重要である。

57 下行結腸癌に対して手術を施行しえた先天性第12因子 欠乏症の 1 例

旭川医科大学 外科学講座 消化器病態外科学分野 1 、旭川医科大学 消化器血液腫瘍制御内科学分野 2 、旭川医科大学 卒後臨床研修七 ンター 3

山田夏生 3 、宮本正之 1 、合地美香子 1 、谷 誓良 1 、土岐康通 2 、大

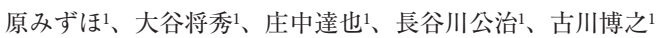

【諸言】先天性凝固第XII因子 (F12) 欠乏症（F12D）は手術患者 の $0.03 \%$ に存在する稀な疾患であり、APTTの著明な延長を認め る。今回我々はF $12 \mathrm{D}$ を伴う下行結腸癌患者に手術を施行したの で報告する。【症例】70才台男性。高血圧、大腸ポリープにて近 医でフォロー中であった。2 年ぶりの大腸内視鏡検査で下行結腸 に $25 \mathrm{~mm}$ 大の 2 型病変を認めた。生検結果はGroup 5 , tub 2 で あった。精查加療目的に当院紹介となった。入院前検査でAPTT $>200$ sec と測定上限超過を認めた。採血部位皮下出血や関節内 出血はなく、既往のポリペクトミーでも問題なかったが、血液内 科へコンサルトしたところ、F12が $3 \%$ 未満と低下しており、 F12Dの診断となった。術前にFFPを 4 単位輸血し、APTTが正 常化したことを確認した後、全身麻酔下に腹腔鏡下結腸左半切除 術を施行した。術中出血傾向は示さず、出血量は $6 \mathrm{ml}$ であった。 術後 2 日目から 8 日目までフォンダパリヌクスを投与したが、出 血傾向や血栓症なく経過良好で退院した。【考察】F12Dでは明 らかな出血症状はなく、逆に線溶系異常により血栓症になりやす いとも言われているが、本邦の報告例ではFFP輸血が行われる ことが多い。【結語】F12Dに対しては、適切な術前管理を行う ことで、安全に手術可能であると考えられる。
58 下行結腸原発性腹膜垂炎の 1 例

独立行政法人 国立病院機構 函館病院 外科1、独立行政法人 国立 病院機構 函館病院 病理診断科 ${ }^{2}$

金子 司 ${ }^{1} 、 山$ 吹 匠1 岡村国茂1、藤原 晶1 高橋 亮1、小室 一輝1、岩代 望1、大原正範1、木村伯子 ${ }^{2}$

原発性腹膜垂炎は, 腹膜垂の栄養血管が捻転や梗塞, 直接圧迫等 により血流を阻害され発生するとされる．多くは保存的加療で軽 快するが, 腹壁や多臓器と癒着している場合, イレウスの原因と なっている場合など, 保存的加療での改善にそしいと予想される 際には, 外科的切除も考虑される. 症例は48歳男性。左下腹部痛 を主訴に当院を受診し，媳室炎の疑いで抗生剤を経口投与され， 症状は消失した。18日後に再び腹痛を自覚したため近医を受診し， 翌日精查加療目的に当院当科紹介となった。来院時は発熱なく, 左下腹部に限局する圧痛を認めたが, 腹膜刺激徵候は明らかでな かった。採血検查では, 白血球増多や CRPの上昇を認めなかった。 腹部造影 CTでは, 下行結腸間膜の対側で, 腸管及び腹壁に接す る脂肪織濃度の上昇を認めた。腹部エコーでも, 同部位に辺縁が 粗雑な卵円型の低エコー腫瘤を認めた。下部消化管内視鏡検查で は，頽室など炎症の原因となる所見は明らかでなかった。以上の 所見から, 原発性腹膜垂炎と診断し, 保存的加療で改善にそしい こと, 腹壁との癒着が疑われること, 患者本人が手術を強く希望 したこと, 炎症が限局し外科的切除での根治が見込めることなど から, 腹腔鏡下腹膜垂切除を施行した．摘出標本は楕円球形の腫 瘤であり, 病理組織学検查では出血と繊維化を伴う, 脂肪組織の 限局的炎症が認められた，術後は合併症なく，症状は消失し，術 後 4 日目に退院となった. 若干の文献的考察を加え, 報告する.

\section{9 肺移植後に腸管囊胞様気腫症をきたした 1 例} 市立釧路総合病院 外科

大塚慎也、廣瀬和幸、宮崎 大、齋藤博紀、井上 玲、福田直也、 佐藤暢人、飯村泰昭、長谷川直人

症例は62歳、男性。特発性肺線維症に対し、2015年に他院で肺移 植を施行された。以後当院呼吸器内科に通院し、ステロイド・免 疫抑制薬、 $\alpha$-グルコシダーゼ阻害薬（ $\alpha-\mathrm{GI})$ などを内服して いた。2017年、肺炎疑いで治療中に、腸管壁の気腫の所見を認め 当科紹介となった。症状はなく、CTにて結腸の壁内に気腫、ま た小腸にfree airを認め、腸管囊胞様気腫症と診断した。腸管壊 死や消化管穿孔を疑う所見は認めなかった。保存的に酸素療法を 開始、また $\alpha-\mathrm{GI}$ の内服を中止し、画像所見は改善した。現在ま で本症の再燃は認めていない。本症は、腸管の粘膜下や漿膜下に 含気性囊胞が出現する稀な疾患である。さまざまな原因が提唱さ れており、本症例では $\alpha-\mathrm{GI}$ の内服に加え、肺移植後のステロイ ドや免疫抑制薬の長期使用が発症の誘因になったと考えられた。 肺移植後の管理ではステロイド・免疫抑制薬が必須だが、本症の リスクとなりうるため、腹部画像にも留意していく必要がある。 
60 上腸間膜静脈血栓症を伴った急性虫垂炎に対し待機的 腹腔鏡下虫垂切除術を施行した 1 例

$\mathrm{JA}$ 北海道厚生連 帯広厚生病院 外科

和田秀之、倉谷友崇、桑原尚太、加藤航平、武藤 潤、市之川正 臣、吉岡達也、村川力彦、池田 篤、松本 讓、大竹節之、大野 耕一

症例は58歳男性。腹痛、発熱を主訴に当院救急外来を受診。CT で虫垂の腫大と回結腸静脈から上腸間膜静脈にかけての高吸収域 を認め、上腸間膜静脈血栓症を伴った急性虫垂炎と診断された。 消化器内科に入院し抗菌薬投与、ヘパリンによる抗凝固療法が開 始されたが、第 3 病日のCTで虫垂膿瘍と血栓の門脈本幹への伸 展が見られた。第 4 病日に当科紹介となったが開腹回盲部切除術 となる可能性が高いと判断し保存的加療を継続した。CT再検で 虫垂炎は改善、血栓は縮小し、ワーファリン内服に変更し第21病 日に退院、第73病日に腹望鏡下虫垂切除術を施行した。上腸間膜 静脈血栓症は腸間膜静脈の血流障害により腸管の櫫血を来す比較 的稀な疾患であり、腹腔内炎症性疾患はその原因の一つとされる。 原因の除去を目的とした早期の外科手術が有用とされるが、血栓 について厳重に経過観察した上であれば、待機的虫垂切除術は選 択肢の一つになり得ると考えられた。

61 貧血を主訴として発見された小腸リンパ管腫の 1 例 北海道医療センター 外科1、北海道医療センター 消化器内科 2 北海道医療センター 病理部病理診断科 ${ }^{3}$

佐藤 彩1 植村一仁 1 小林正幸1、三野和宏1、高橋宏明1、佐々 木塁、木村太一 3

【緒言】小腸リンパ管腫は稀な疾患であり，術前診断に難渋する ことが多い，今回、貧血を主訴として発見された小腸リンパ管腫 の 1 例を経験したので報告する.【症例】64歳男性. 貧血の原因 精查目的に当院消化器内科を紹介受診. 上部・下部内視鏡検查で 出血源は認められなかった. 小腸内視鏡・造影検查で空腸に白色・ 顆粒状・易出血性の粘膜下腫瘍を認め, 内腔は狭窄しており, 生 検でLymphangioma と診断された．2018年 4 月，腹腔鏡下小腸 部分切除術を施行. 漿膜面に静脈の怒張と白色隆起性病変を認め た. 病変を含む空腸 $15 \mathrm{~cm}$ を切除し、機能的端々吻合した. 病理 結果はLymphangioma (免疫染色でD 2-40陽性), 悪性所見は認 めなかった. 術後経過は良好で, 貧血も改善し術後 9 日目に退院 した.【考察】消化管発生のリンパ管腫はリンパ管腫全体の $0.1 \%$ 以下と報告されており, 小腸リンパ管腫はさらに稀な疾患である. 小腸リンパ管腫について，文献学的考察を加えて報告する.

62 術前診断が困難であった腸間膜炎症性偽腫瘍の一例 旭川医科大学 外科学講座 消化器病態外科学分野1 旭川医科大学 病院 病理部 2

合地美香子1、長谷川公治1、庄中達也1、大谷将秀1、宮本正之1 谷 誓良 ${ }^{1}$ 、湯澤明夏 ${ }^{2} 、$ 武井英博 ${ }^{2}$ 、松野直徒 1 、古川博之 ${ }^{1}$

【はじめに】炎症性偽腫瘍は肺や肝臓、脾臓などの実質臓器に発 生することが多い非腫瘍性腫瘤性病変であるが、術前に悪性腫瘍 と鑑別することは困難とされている。今回、術後に腸間膜炎症性 偽腫瘍と診断された症例を経験したので報告する。【症例】60歳 代男性、胃腸炎症状で前医受診した。左上腹部に腫瘤を触知し腹 部 CTで腹腔内腫瘤を認め、精查目的に当院紹介受診となった。 既往歴には高血圧、脂質異常症があり開腹歴はなかった。身体所 見は左上腹部に鶏卵大の腫瘤を触知するも圧痛は認めなかった。 血液検查所見ではWBC $7,160 / \mu \mathrm{L} 、 \mathrm{CRP}<0.10 \mathrm{mg} / \mathrm{L} 、 \mathrm{CEA}$
0.7ng/ml、CA19- 9 5.0U/ml、sIL-2R 5037.0 U/mlであった。 造影 CT では空腸近傍に $84 \times 63 \times 90 \mathrm{~mm}$ の境界明瞭で内部の造影 効果が不均一な腫瘤を認めた。EUSでは $75.5 \times 64.6 \mathrm{~mm}$ の内部不 均一な hypoechoic massを認めた。FDG-PET/CTでは同病変に SUVmax4.7 $\rightarrow 5.9$ の集積を認めた。画像所見より小腸腫瘍（GIST 疑い）の術前診断で手術の方針となった。術式は開腹空腸部分切 除術で手術時間は 3 時間28分、出血量は $156 \mathrm{ml}$ であった。術中所 見はTreitz勒帯から約 $5 \mathrm{~cm}$ 肛門側の空腸間膜内に約 $10 \mathrm{~cm}$ 大の 腫瘤を認め、腫瘤を含む約 $20 \mathrm{~cm}$ の空腸を切除し機能的端端吻合 とした。肉眼所見は腫瘤の大きさは $11.5 \times 8.2 \times 6.5 \mathrm{~cm}$ で、一部出 血・壊死様部分を伴う軟らかい乳白色調充害性腫瘍であった。組 織所見では腫瘍は線維性に肥厚した被膜に包まれたリンパ節に相 当しリンパ節の炎症性偽腫瘍の診断となった。術後経過は良好で 術後11日目に退院となった。【結語】術前診断が困難であった腸 間膜炎症性偽腫瘍の一例を経験したので、文献的考察を含めて報 告する。

63 当院における大腸穿孔例の予後および術後在院日数に 関する予測因子の検討

北海道社会事業協会帯広病院 外科

水上達三、松井博紀、大畑多嘉宣、高橋 徹、橋本 卓、阿部厚 憲

【はじめに】大腸穿孔は沉発性腹膜炎から敗血症性ショックを高 頻度に合併し、DICから多臓器不全へと移行し、死亡率が $1-3$ 割と予後不良の疾患である。病態が重篤化しやすいため、救命出 来たとしても術後在院期間が長期化する症例もみられ、退院後の ADLやQOLに大きな影響を及ぼす可能性がある。【対象と方法】 2012年 4 月から 2017 年 8 月までに大腸穿孔による腹膜炎の診断で 臨時手術を行った38例（虫垂穿孔は除く）を対象とし、術前併存 疾患、穿孔部位とその原因および手術術式、術後合併症と共に、 予後に関しては生存群と死亡群、術後在院日数に関しては短期在 院群（ミ28日）と長期在院群（>28日）に分けて、患者背景や周 術期因子に関して比較検討を行った。【結果】術前併存疾患保有 率は71.1\%で、高血圧 (19例)、糖尿病 $(6$ 例)、呼吸器疾患 $(6$ 例 $)$ などであった。穿孔部位は S 状結腸（16例）、直腸（13例）、上行 結腸（ 5 例）の順で、原因は悪性疾患 $(17$ 例 $)$ 、憩室 $(11$ 例 $)$ 、糞 便性（7 例）の順であった。術式はハルトマン手術が25例と最多 であり、上行結腸穿孔以外には全例カバーリングを含めたストマ を造設した。術後合併症は21例 (55.3\%) で発生し、創感染が7 例と最多であった。予後に関しては生存群は35例、死亡群は 3 例 であり死亡率 $7.9 \%$ であった。予後に関する因子の単変量解析で は術前 CRP 高值 $(\mathrm{P}<0.01)$ 、術後 DIC $(\mathrm{P}=0.018)$ 、PMXあるい は CHDF施行例（P=0.025）が生存群に比して死亡群で有意に多 く、多変量解析では術前 $\mathrm{CRP}$ 高值 $(\mathrm{P}=0.049)$ が独立した予後不 良因子であった。術後在院日数に関する因子の単変量解析では、 Hinchey IV 度の腹膜炎 $(\mathrm{P}=0.028)$ 、術前 $\mathrm{Alb}$ 低值 $(\mathrm{P}=0.026)$ 、術 後DIC $(\mathrm{P}<0.01)$ およびPMXあるいは CHDF 施行例 $(\mathrm{P}=0.018)$ が短期在院群に比して長期在院群で有意に多く、多変量解析では 術後DIC（P=0.027）が独立した因子であった。【結語】当院にお ける大腸穿孔例において、術前 $\mathrm{CRP}$ 高值が予後不良の、術後 DICが術後在院日数長期化に関する独立した因子であった。大腸 穿孔例においては、手術や抗菌薬などによる炎症のコントロール に加えて、DIC 治療を含めた術後集中治療が肝要であると考えら れた。 
64 麻酔下に摘出可能であった肛門異物の 1 症例 JR札幌病院

太田盛道、柏木清輝、田山慶子、植木知身、鶴間哲弘、平田公一 直腸異物はしばしば実臨床上経験されるが、手術などの侵襲的な 治療が必要となることもあり、術前の診断が重要と考えられる。 今回我々は問診並びに造影 CTを元にした治療方針を立て、非侵 襲的に直腸異物を摘出することができた 1 症例を紹介する。症例 は65歳男性、瓢箪状の健康器具を朝に肛門から挿入。前医肛門科 で摘出不能との判断となり同日夕方に当科紹介となる。CTでは 15-16cm 程度の大きさであり、上端は岬角付近に到達していた。 free air等は認めなかった。

腹部は緊満しておらず、圧痛は認めなかった。内視鏡下での摘出 が提案されたが、形状より異物に穴を開けても容積縮小効果にそ しいと考えられ、筋弛緩がかかった状態での処置が望ましいと考 えられた。

手術室にて砕石位、全身麻酔下とし、筋驰緩が得られた際に、体 表から恥骨背面にある異物を触知することが可能であった。その ため用手的な摘出を試みることとした。䎵骨上からの体表用手圧 迫を行い、異物を肛門側へと押しながら、同時に肛門より用手的 に直接引き出すことが可能であった。手術時間は 2 分、出血なし。 翌日には炎症所見もなく退院となった。

多様な異物が肛門から㨂入されることが昨今経験されるが、本症 例から得られた事は材質と形状そして位置情報を事前に把握する ことにより、過大な侵襲処置が防げられたことと考えられる。

65 特発性腸間膜静脈硬化症を背景とした腸管穿孔に対し て、穿孔部縫合と回腸人工肛門造設により救命し得た一例 斗南病院

郷雅、鈴木善法、福田純已、横山啓介、櫛引敏寞、森 大樹、 佐藤大介、才川大介、芦立嘉智、林 諭史、川田将也、川原田陽、 北城秀司、奥芝俊一

特発性腸間膜静脈硬化症は腹痛、便秘、腹部膨満を主症状とし、 $\mathrm{CT}$ 上で右半結腸の腸間膜静脈に一致した石灰化を認める稀な腸 疾患である。症例は84歳、女性。右側腹部痛を主訴に近医を受診、 消化管穿孔疑いで当院へ搬送された。精查の結果、上行結腸の穿 孔疑いとして、同日手術を施行した。手術は開腹で行い、上行結 腸に $1 \mathrm{~cm}$ 程度の穿孔部を認めたため同部位を縫合、回腸人工肛門 を造設し手術を終了した。特発性腸間膜静脈硬化症は特定の漢方 薬の長期服用と関連があるとされ、慢性的な経過をたどりやすい ため、漢方薬の中止などの保存的治療が第一選択となる。本症例 のように穿孔を機に発見された報告は少なく、手術に至った場合 は広範囲に結腸を切除する方法が選択されることが多い。今回、 特発性腸間膜静脈硬化症を背景とした腸管穿孔に対して、穿孔部 縫合と回腸人工肛門造設により救命し、良好な経過をたどった一 例を経験したので文献的考察を含めて報告する。

66 穿孔および膿瘍形成を伴った肺癌小腸転移の 1 例 勤医協中央病院 外科

松田隆志、吉田 信、石井健一、諸星直輝、浅沼和樹、奈良智志、 中村祥子、阿部慎司、大黒聖二、田尾嘉浩、川原洋一郎、林 浩 三、後藤 剛、山川智士、鎌田英紀、高梨節二、樫山基矢、石後 岡正弘、河島秀昭、松毛真一

症例は71歳男性. 3 ケ月前から肺腺癌 Stage IVに対してぺムブロ リズマブの投与を受け，薬剤性肝障害や間質性肺炎発症のため, ステロイド治療（維持量 $25 \mathrm{mg} /$ 日）を受けていた，全身倦怠感
が出現して当院を受診し，腹部単純 CT 検査で腹䏶内遊離ガス像 と小腸の壁肥厚を認めたが，腹部所見がそしく保存的治療の方針 で入院した. 消化管造影検查で小腸の穿孔所見は認めなかったが, 入院13日目に悪寒，発熱が出現した。腹部造影 CT検査で前回の 遊離ガス像の部位に膿瘍形成を認め, 入院16日目に手術を行った。 大網，横行結腸，小腸で膿瘍䏶が形成されていた，小腸内に弾性 硬で大小多数の腫瘤を触知し，一部漿膜面に変化があり，その一 部で穿孔を起こしたと考えて, 小腸を部分切除した，病理組織学 的検查で肺癌の小腸転移と診断した。また穿孔部と考えた腫瘍で は壊死もあり，穿孔の原因として化学療法による腫瘍壊死が示唆 された。

67 超高齢者の盲腸捻転に対し腹腔鏡下盲腸捻転解除術を 施行した一例

市立旭川病院 外科

䆶田武哲、村上慶洋、本谷康二、阿部紘丈、福永亮朗、笹村裕二、 武山 聡、子野日政昭

【症例】96歳男性。認知機能障害にて施設入所中, 夜間に腹痛を 訴えていたが排便も認めており経過観察していた。翌日，腹痛の 訴えなく普段通り生活していたが，同日夜に再度腹痛を訴えたた め, 当院救急外来に搬送された。CT検查では, 盲腸に狭窄を認 め口側の腸管は著明な拡張を認めた。回盲部は盲腸の右側に位置 していたことから盲腸捻転が疑われた。もともと便秘症もあり結 腸全体に霬便を伴う拡張を認め, 内視鏡的整復は困難と判断し, 入院翌日に手術を施行した。腹腔鏡で観察すると, 盲腸が足側か ら見て反時計回りに $180^{\circ}$ 捻転しており, 水平型の盲腸捻転と診断 した。腹腔鏡下に捻転解除し，腸切除施行せず手術を終了した。 術後経過は良好で, 術後 5 日目に軽快退院となった。

結腸軸捻転症の多くはS 状結腸に発症し, 盲腸に起こることは比 較的稀である。今回我々は腹腔鏡下に盲腸捻転を解除した症例を 経験したため, 若干の文献的考察を加え報告する。

68 空腸瘦に起因する胃癌術後イレウスの 1 例 小樽掖済会病院 外科 1 、札幌医科大学 消化器 - 総合、乳腺 - 内分 泌外科学講座 ${ }^{2}$

三浦 亮、野田 愛1、中山健太 ${ }^{1}$ 向谷充宏 ${ }^{1}$ 佐々木一晃 1 、竹 政伊知朗 2

症例は77歳男性。進行胃体上部癌の診断にて当科紹介となり、胃 全摘術、Roux-en-Y再建を施行した。手術時には術後摂食障害 の可能性を考慮し、チューブ空腸瘦造設を併施した。術後 7 日目 から食事を再開、問題なく経過していたが、術後15日目に嘔吐を 認めた。腹部CTにて、十二指腸および上部空腸の著明な拡張と、 空腸瘦刺入部を軸とした腸間膜の渦巻き様所見を認め、空腸瘦を 起因とした腸閉塞と診断し再手術を施行した。腹腔内では空腸瘦 造設部を中心に空腸が時計回りに捻転した状態で癒着し、狭窄源 となっていた。捻転の解除と空腸瘦抜去を行い、手術を終了した。 再手術後の経過は良好であった。高侵襲な消化器癌手術時には、 術後の経口掑食不良を補う目的で空腸瘦造設が多くの施設で行わ れているが、同様の報告は少なく、発症例は比較的稀と考えられ る。今回は予防策を含めて考察を加え、報告する。 
69 腸重積で発症した小腸笳線維芽細胞腫の 1 例 札幌センチュリー病院 外科・乳腺外科1、札幌診断病理学センタ $-2$

小西和哉1、荒谷 純 1 、永㴊 誠1 坂本 尚1 1 賀来 亨 ${ }^{2}$ 炎症性筋線維芽細胞腫瘍は、著明な炎症細胞浸潤を伴う筋線維芽 細胞の増殖からなる腫瘍で、肺原発の報告が多く消化管発生例は 報告が少ない。我々は、腸重積で発症した小腸炎症性筋線維芽細 胞腫瘍症例を経験したので報告する。患者は87歳女性。主訴は心 窝部痛。現病歴は 1 か月前より心窩部痛を自覚し近医で内視鏡検 查を施行され胃炎と診断された。 H 2 ブロッカーを処方されたが 改善ないため当院を受診した。現症は腹部は平坦で圧痛なし。 $\mathrm{CT}$ で $4 \times 3 \mathrm{~cm}$ の造影効果のそしい小腸腫瘍を認め、腸重積の 所見があったので緊急手術施行（小腸切除）した。術後経過良好 で術後 12 日に退院した。腫瘍は $33 \times 30 \times 30 \mathrm{~mm}$ の粘膜下腫瘍で病 理組織所見は膠原線維性基質を伴う紡錘形細胞の増殖を認め、 Vimentin：陽性、 $\alpha$-SAM：陽性、ALK：弱陽性、Desmin：血 管壁の一部に陽性、S-100：陰性、C-kit：陰性、CD34：陰性、 Parakeratin：陰性 Ki67：散見される程度で炎症性筋線維芽細胞 腫瘍と診断された、術後17か月経過したが無再発生存中である。

70 胃切除後食道癌根治術の回結腸再建において通過障害 をきたした 1 例

手稲溪仁会病院 外科

木ノ下義宏、武内慎太郎、今村清隆、渡邊祐介、高田 実、加藤 健太郎、安保義恭、中村文隆、樫村暢一

胃切除後の食道癌手術は少なからず経験し、残遺全摘後の再建と して回結腸を用いる場合がある。食道回腸吻合で端側吻合のステ ッキが拡張することにより本来のルートを圧排し通過障害が発症 した症例を経験したので報告する。60歳代男性。2017年 3 月胸部 下部食道癌根治術、胸骨後回結腸再建を行なった。術後30病日軽 快退院となった。その後徐々に嚥下困難が生じ、食道造影で回腸 パウチにバリウムが貯留し通過障害を認めるようになった。同年 6 月回腸パウチの切除を行なった。食事摂取良好となり29日で退 院となった。しかし再び食事摂取困難となり食道造影では前回と 同様に回腸パウチの拡大が認められた。2018年 3 月再度手術を行 い、パウチを含めた吻合部切除、頸部食道回腸端々吻合を行なっ た。その後通過障害なく食事摃取可能となった。ステッキ拡張に よる通過障害の場合、手術はパウチ切除ではなく困難ではあるが パウチを含めて吻合部切除、再吻合が確実に食事摂取可能となる。

\section{1 イレウスを契機に発見された膀胱異物穿孔の一例} 市立室蘭総合病院 外科

木村明菜、小川宰司、渡久山晃、宇野智子、斎藤慶太、佐々木賢 -

【症例】66歳男性。前医入院中に突如腹痛・腹部膨満が出現し、 単純 CTにてイレウスと診断された。保存的治療で改善せず、そ の 2 日後に造影 CTを行ったところ膀胱から腹䏶内へ達する棒状 異物と、骨盤底に膀胱から流出した造影剂の貯留を認め、膀胱内 異物穿孔を疑い加療目的に当院へ搬送となった。【手術】異物の 誤飲・挿入について訪ねたところ当初は否定していたが、繰り返 し確認した結果 1 年前に自慰行為で尿道より鉛筆を挿入したこと が判明。腹腔鏡下に観察すると、膀胱から腹腔内に突出する鉛筆 を認めた。消化管に損傷はなく、鉗子にて回収し穿孔部位を縫合 閉鎖したのちに膀胱鏡で観察を行い、リークのないことを確認。 腹腔内を生理食塩水で洗浄後、左右横隔膜下・膀胱直腸窩にドレ
ーンを留置して手術を終了した。【まめ】膀胱尿道異物の多く は性的趣向による抻入であり、その特殊な契機から問診が重要な 役割を担う。若干の文献的考察を加え、報告する。

\section{2}

GAPP分類により中分化型と診断された褐色細胞腫の

1 例

国立病院機構函館病院 外科 1 、国立病院機構函館病院 病理診断科 2 今成隼人 1 、高橋 亮、金子 司 1 、藤原 晶 ${ }^{1}$ 、山吹 匠 1 、小室 一輝 ${ }^{1}$ 、岩代 望1、大原正範 ${ }^{1} 、$ 木村伯子 ${ }^{2}$

褐色細胞腫と傍神経節細胞腫の転移率や予後は様々な方法で予測 がなされている。 その一つにGrading of Adrenal Pheochromocytoma and Paraganglioma (GAPP) が存在する. GAPPは褐色 細胞腫及びパラガングリオーマの悪性化のリスクを高分化型, 中

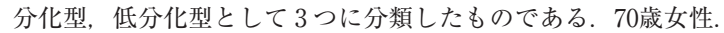
肺非結核性抗酸菌症にて治療中, CTにて左後腹膜に腫瘤性病変 を認めた，造影 CTでは左腎腹側に $40 \mathrm{~mm} の$ 造影効果の強い腫瘤を 認めた. MIBG シンチグラフィでは同部位に集積を認めた. 尿中, 血中カテコラミン高值を認めた．以上より褐色細胞腫の診断で, 腹腔鏡下左副腎摘出術を施行した。手術病理の結果は褐色細胞腫 でGAPPにて組織学的構造 : zellballen, 細胞密度 : low, Comedo Necrosis：なし, 血管または被膜への浸潤 : なし, Ki67陽性率： $3.4 \%$, 産生カテコラミン：ノルアドレナリンで計 3 点から悪性 度は中分化型であった，術後は合併症なく退院となった，病理組 織検查結果から特に慎重な経過観察が必要と考えられる褐色細胞 腫の 1 例を経験した.

73 胃癌根治手術中の血圧上昇を契機に発見された副腎外 傍神経節腫の 1 例

勤医協中央病院 外科

石井健一、吉田 信、松田隆志、諸星直輝、浅沼和樹、奈良智志、 大黒聖二、高梨節二、樫山基矢、石後岡正弘、河島秀昭、松毛真

症例は68歳男性. 胃癌の内視鏡治療後, 病理所見で脈管侵襲陽性 のため追加切除の方針となり当院へ入院. CT 検査で腹部大動脈 と下大静脈の間に径 $38 \times 14 \mathrm{~mm}$ の境界明暸で内部不均一な腫瘤を 認め, 傍大動脈リンパ節腫脤や神経鞘腫などの後腹膜腫瘍を考え て胃切除と同時摘出の方針として手術を行った，後腹膜腫瘤の周 囲を操作した際、著明な血圧上昇と心電図異常が出現し，手術を 中止して精查を行った. 蓄尿検查でカテコラミン高值, MRI T 2 強調像で高信号, MIBG シンチグラフィーで腫瘍への取り込み を認め, 副㹂外傍神経節腫と診断. 初回手術から 2 週間後に再手 術を行った，腫瘍周囲の剥離の際に多少の血圧変動を認めたが, 血管処理後には安定した．腫瘍摘出後に胃癌根治手術を行って閉 腹. 病理所見から傍神経節腫と診断した，後腹膜腫瘍の中でも傍 神経節腫は比較的稀であり, 正常血圧で他に自覚症状がない場合 でも，腫瘍の局在から本疾患を念頭におく必要がある。

74 切除した 1 例

小樽市立病院 外科

村田竜平、小林展大、渡辺義人、越前谷勇人

脂肪肉腫は全腫瘍の $0.16 \%$ を占める稀な疾患である. 腹腔内．後 腹膜に同時発生し, 腫瘍の尿管圧迫による水腎症を認めたため 2 期的に摘出した症例を経験認め報告する。症例は46歳男性で，腹 部の張りと倦怠感を自覚して当院を受診された，造影 CTでは腹 
腔内に $23 \mathrm{~cm}$ 大, 左腎直下に $14 \mathrm{~cm}$ 大の内部不整な腫瘤を認めた

腹胿内腫瘤は内部に液面形成を認め, 腫瘍壊死による敗血症が示 唆された. また，腫瘍の尿管圧迫による右水腎症を認めたため, まず腹䏶内腫瘤を開腹にて摘出した，術後経過は良好であり， 17 日目に一旦退院した，腎機能の改善が得られたため，43日目に左 後腹膜腫瘍摘出術を腹部同一創から行った。病理では共に粘液型 脂肪肉腫であった，術後13日目に無事退院となった，脂肪肉腫は 稀な疾患であり，文献的考察を加えて報告する。 